\title{
Hak atas Pekerjaan bagi Penyandang Disabilitas di Sektor Publik: Antara Model Disabilitas Sosial dan Medis
}

\author{
Muhammad Dahlan ${ }^{\star}$ Syahriza Alkohir Anggoro ${ }^{\star \star}$ \\ ^Fakultas Hukum Universitas Brawijaya \\ dahlan@ub.ac.id

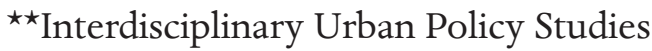 \\ syahrizaalkohir@gmail.com
}

\section{Abstract}

The opportunity to fulfill the rights to work for persons with disabilities has been increasing since the ratification of Convention on the Rights of Persons with Disabilities (CRPD). Indonesia has adopted a "quota scheme" through the Law Number 8 of 2016 on Persons with Disabilities where government institution has set a minimum quantity of two percent as the number of workers for persons with disabilities as affirmative action targeted at promoting human rights. This article examines the progress of the legal framework for persons with disabilities by using a case study in civil cervants in the public sector. We argue that despite Indonesia's disability legal regime has pushed the social model of disabilities that promotes human rightsbased approach, its implementation is still based on the medical model of disability, in which it sees persons with disabilities on physical condition, and thus, they are assumed to be able to work in a certain field determined by the government. This article argues that affirmative policy does not provide equal opportunities to persons with disabilities as the special formation and medical requirements prevent them from applying for occupations that match their interests and educational background. The use of the medical model of disability in providing employment opportunities in the public sector prevents the level of participation and the formation of an inclusive workplace environment.

Keywords: persons with disabilities; rights to work; Indonesia's legal reform; human rights; public sector. 


\section{Abstrak}

Peluang untuk memenuhi hak atas pekerjaan bagi para penyandang disabilitas terus meningkat sejak ratifikasi Convention on the Rights of Persons with Disabilities (CRPD). Indonesia mengadopsi "skema kuota" melalui UU Nomor 8 Tahun 2016 tentang Penyandang Disabilitas di mana institusi negara menetapkan minimal dua persen jumlah formasi pekerja bagi para penyandang disabilitas sebagai tindakan afirmatif yang ditargetkan untuk mempromosikan hak asasi manusia. Artikel ini memeriksa sejauh mana kerangka kerja hukum disabilitas di Indonesia memfasilitasi pemenuhan hak atas pekerjaan bagi penyandang disabilitas dengan menggunakan contoh kasus pada penyelenggaraan ketenagakerjaan di sektor publik. Kami berpendapat bahwa meskipun rezim hukum disabilitas di Indonesia menekankan model sosial disabilitas yang mempromosikan pendekatan berbasis hak asasi manusia, implementasinya masih didasarkan pada model medis disabilitas yang memandang penyandang disabilitas berdasarkan kondisi fisik dan karenanya diasumsikan hanya dapat masuk pada bidang pekerjaan yang telah ditentukan oleh negara. Artikel ini berpendapat bahwa kebijakan afirmatif tidak memberikan peluang yang setara bagi penyandang disabilitas karena formasi khusus dan persyaratan medis menghambat mereka untuk melamar pada bidang pekerjaan yang sesuai dengan minat dan latar belakang pendidikannya. Penggunaan model medis disabilitas dalam penyelenggaraan kesempatan kerja di sektor publik pada gilirannya menghambat tingkat partisipasi dan pembentukan lingkungan kerja yang inklusif.

Kata kunci: penyandang disabilitas; hak atas pekerjaan; reformasi hukum Indonesia; hak asasi manusia; sektor publik.

\section{A. Pendahuluan}

Artikel ini membahas persoalan sekitar pemenuhan hak atas pekerjaan bagi penyandang disabilitas dalam pemikiran hukum kontemporer sehubungan dengan munculnya The United Nation Convention on the Rights of People with Disabilities (CRPD) pada 2006. Konvensi ini mengadopsi model sosial disabilitas (social model of disability) yang dimaksudkan untuk mempromosikan martabat yang melekat (inherent dignity) di setiap penyandang disabilitas di mana negara harus memperlakukan mereka sebagai subjek hukum yang 
setara dan memiliki kesempatan yang sama untuk menggunakan hak dan kebebasan mendasar. ${ }^{1}$ CRPD merupakan contoh rezim hukum internasional yang mengedepankan apa yang disebut Mark Goodale sebagai "hukum simpatik" (sympathetic law); suatu teori dan praktik hukum yang melayani fungsi kemanusiaan dan perubahan sosial untuk kesejahteraan dan keadilan sosial. ${ }^{2}$ Kemunculan CRPD tidak dapat dilepaskan dari kesadaran bahwa penyandang disabilitas masih hidup dalam kondisi yang sangat rentan dan miskin karena berbagai hambatan yang menyebabkan hilangnya kesempatan untuk mengeksplorasi bakat dan minat individu masing-masing. Pemenuhan terhadap hak atas pekerjaan, dengan demikian, menjadi salah satu agenda utama dalam memaksimalkan potensi, kontribusi dan partisipasi kegiatan ekonomi yang lebih besar bagi penyandang disabilitas.

Sejak ratifikasi CRPD melalui Undang-Undang Nomor 19 Tahun 2011 tentang Pengesahan Konvensi Hak-Hak Penyandang Disabilitas dan Undang-Undang Nomor 8 Tahun 2016 tentang Penyandang Disabilitas (UU Penyandang Disabilitas), Indonesia secara bertahap bergerak menjauh dari tradisi hukum paternalistik dalam memandang penyandang disabilitas menuju tradisi hukum yang berorientasi hak asasi manusia (HAM) termasuk di antaranya dalam memandang hak atas pekerjaan (right to work) di sektor publik. ${ }^{3}$ UU Penyandang Disabilitas mengadopsi pendekatan model sosial disabilitas yang berorientasi pada pandangan anti-diskriminasi 'dalam upaya mengembangkan diri sebagai manusia yang bermartabat.'4 Ini secara normatif telah diatur pada Pasal 11 UU Penyandang Disabilitas yang memberikan jaminan bahwa setiap penyandang

1 Anna Lawson dan Mark Priestley, "The Social Model of Disability Questions for Law and Legal Scholarship?”, dalam Routledge Handbook of Disablity Law and Human Rights, ed. Peter Blanck dan Eilionoir Flynn (Oxon: Routledge, 2017), hlm. 5.

2 Mark Goodale, "The Globalization of Sympathetic Law and Its Consequences”, Law \& Social Inquiry, 27, 3 (2002), hlm. 597.

3 Lihat Agung Wardana dan Ni Putu Yogi Paramitha Dewi, "Moving Away from Paternalism: the New Law on Disability in Indonesia”, Asia-Pacific Journal on Human Rights and the Law, 18 (2017), hlm. 175.

4 Lihat penjelasan UU Penyandang Disabilitas. 
disabilitas berhak memperoleh pekerjaan yang diselenggarakan oleh pemerintah, pemerintah daerah, atau sektor swasta tanpa diskriminasi melalui kuota dua persen untuk pekerjaan publik dan satu persen untuk sektor privat. Pada 2017 dan 2018 misalnya, Indonesia mulai memperkenalkan kebijakan afirmatif dengan menetapkan sejumlah persyaratan tertentu untuk ragam disabilitas tertentu dan kualifikasi pendidikan yang disalurkan pada formasi khusus yang diverifikasi langsung secara medis oleh panitia. ${ }^{5}$ Formasi khusus dipromosikan sebagai bentuk kebijakan afirmatif yang mendorong para penyandang disabilitas untuk masuk pada prioritas-prioritas yang ditetapkan oleh pemerintah dengan tujuan mendorong secara cepat pemenuhan hak atas pekerjaan bagi penyandang disabilitas. ${ }^{6}$ Banyak negara mengadopsi pendekatan semacam ini karena diklaim sejalan dengan model disabilitas sosial yang melahirkan kewajiban negara untuk mengambil tindakan konkret yang telah ditargetkan atas pemenuhan hak untuk mendapatkan pekerjaan dan hak untuk bekerja dalam kondisi yang adil dan setara. ${ }^{7}$

5 Lihat Poin F Lampiran PermenPAN-RB Nomor 36 Tahun 2018 tentang Kriteria Penetapan Kebutuhan Pegawai Negeri Sipil dan Pelaksanaan Seleksi Calon Pegawai Negeri Sipil (CPNS) Tahun 2018 (Permen PAN-RB 2018).

6 Fajri Nursyamsi, "Formasi Khusus Disabilitas CPNS 2018: Pisau Bermata Dua”, https://pshk.or.id/blog-id/formasi-khusus-disabilitas-cpns-2018pisau-bermata-dua/, diakses 22//8/2020.

7 Pendekatan formasi khusus dan sistem kuota pertama kali dikembangkan pada 1970an berdasarkan pengalaman negara-negara Eropa dan Amerika Utara untuk mempekerjakan veteran perang. Pada 1980an, International Labour Organization (ILO) mengesahkan Konvensi Nomor 159 tentang Vocational Rehabilitation and Employment of Disabled Persons 1983 yang menyerukan negara-negara anggota untuk merumuskan kebijakan ketenagakerjaan nasional bagi penyandang disabilitas, yang mencakup sistem kuota, formasi khusus, dana rehabilitasi nasional, dan lain sebagainya. Konvensi ini meletakkan dasar bagi ILO untuk mengadvokasi model kebijakan formasi khusus dan kuota sebagai salah satu solusi mengatasi tuntutan pemenuhan hak atas pekerjaan bagi penyandang disabilitas. Banyak negara-negara emerging market (khususnya di Asia Tenggara, Timur dan Amerika Latin) menyukai model kebijakan yang dipromosikan ILO karena dapat mempertemukan permintaan akses keadilan sosial bagi penyandang disabilitas dalam pasar tenaga kerja. Meskipun CRPD sendiri tidak mengadopsi secara formal sistem kuota dan formasi khusus sebagai salah satu aspek yang diperlukan dalam bidang ketenagakerjaan, pada saat 
Meskipun langkah-langkah ini dipuji sebagai "realisasi progresif” HAM, ada sejumlah perdebatan yang muncul, apakah kebijakan afirmasi yang digulirkan untuk memenuhi hak atas pekerjaan ini terlalu sempit untuk disebut sebagai realisasi pemenuhan HAM bagi penyandang disabilitas, mengingat jumlah kuota sebenarnya tidak diatur dalam CRPD. Karena itu, ia lebih merupakan interpretasi legislator UU Penyandang Disabilitas untuk memudahkan implementasi di lapangan. Organisasi disabilitas barubaru ini mempertanyakan formasi khusus seleksi CPNS 2018 yang dinilai justru mendiskriminasi para penyandang disabilitas karena persyaratan-persayaratan formal yang berkaitan dengan keterbatasan fisik dan kualifikasi pendidikan yang ditetapkan, sehingga membatasi mereka pada pilihan yang telah ditentukan. ${ }^{8} \mathrm{Hal}$ ini menimbulkan kekhawatiran di antara para penyandang disabilitas yang tidak dapat melamar pada bidang-bidang di luar yang telah ditentukan

ini banyak negara anggota CRPD berbagi pandangan yang sama menggunakan sistem kuota dan formasi khusus untuk menginterpretasikan amanat CRPD dan model sosial disabilitas dalam pemenuhan hak atas pekerjaan bagi penyandang disabilitas melalui legislasi nasional mereka masingmasing. Namun demikian, para akademisi disabilitas, bagaimanapun, tetap memperdebatkan efektivitas kebijakan formasi khusus dan sistem kuota karena perbedaan tingkat industrialisasi, latar belakang pendidikan dan kondisi sosial ekonomi yang beragam di negara-negara berkembang memerlukan kebijakan ketenagakerjaan disabilitas yang sesuai dengan konteks historis dan kondisi objektif masing-masing negara. Formasi khusus dan sistem kuota dapat secara potensial menghambat atau membatasi penyandang disabilitas terhadap pilihan bidang pekerjaan yang sesuai dengan minat dan latar belakang pendidikannya. Kritik para akademisi juga dibingkai dalam pandangan bahwa kebijakan formasi khusus dan sistem kuota cenderung pragmatis dan mengabaikan kompleksitas persoalan kondisi ragam disabilitas di lapangan. Mengenai perdebatan dan asal usul kebijakan formasi khusus dan sistem kuota, lihat Patricia Thornton, "Employment Quotas, Levies and National Rehabilitation Funds for Persons with Disabilities: Pointers for Policy and Practice”, Gladnet Collection Cornell University, 84 (1998): 1-89; Malcolm Sargeant, Elena RadevishKatsaroumpa, dan Alessandra Innesti, "Disability Quotas: Past or Future Policy?”, Economic and Industrial Democracy, 39, 3 (2018): 404-21.

8 Pusat Studi Hukum \& Kebijakan Indonesia, "Siaran Pers Koalisi Masyarakat Penyandang Disabilitas”, https://pshk.or.id/publikasi/siaran-pers/siaranpers-koalisi-masyarakat-penyandang-disabilitas/, 29/5/2020, diakses $7 / 9 / 2020$. 
yang sesuai dengan minat dan bakatnya. Alih-alih dimaksudkan untuk melindungi HAM para penyandang disabilitas, persyaratan formal yang digulirkan oleh pemerintah untuk memenuhi target kuota pekerjaan sektor publik melalui formasi khusus membawa pesan yang jelas bahwa kebijakan tersebut justru tidak sejalan dengan pembangunan inklusif yang dipromosikan CRPD dan UU Penyandang Disabilitas.

Artikel ini menggunakan contoh kasus pemenuhan hak atas pekerjaan di sektor publik bagi penyandang disabilitas untuk menguji sejauh mana kebijakan yang diarahkan untuk merealisasikan hak tersebut sejalan dengan model disabilitas sosial. Artikel ini berpendapat bahwa meskipun rezim hukum disabilitas di Indonesia menekankan model sosial disabilitas dalam merealisasikan hak atas pekerjaan di sektor publik, implementasinya masih didasarkan pada model medis disabilitas di mana para penyandang disabilitas diidentifikasi berdasarkan kondisi fisik dan dengan demikian diasumsikan hanya dapat masuk pada bidang pekerjaan di sektor publik yang telah ditentukan oleh negara. Kebijakan ketenagakerjaan di sektor publik tidak dirancang untuk memfasilitasi jenis dan kondisi pendukung pemenuhan hak-hak penyandang disabilitas dan didukung oleh persyaratan medis yang dipaksakan dan ditentukan secara sepihak dari atas.

Bagian pertama artikel ini mendiskusikan rezim hukum disabilitas yang diperkenalkan oleh rezim Soeharto untuk menunjukkan adanya pergeseran pemahaman terhadap penyandang disabilitas dari model medis (dan amal) menuju paradigma berbasis HAM pasca reformasi. Sementara model medis memandang penyandang disabilitas sebagai individu penderita kekurangan 'fisik' yang memerlukan penanganan medis dan dukungan amal dari negara, model sosial disabilitas memandang disabilitas sebagai kondisi atau hambatan sosial yang mencegah interaksi orang yang hidup dengan keterbatasan fisik, sensorik, intelektual atau psikologis untuk mengambil bagian dalam masyarakat. ${ }^{9}$ Bagian berikutnya membahas instrumen HAM internasional yang telah diadopsi Indonesia,

9 Arlene S. Kanter, The Development of Disability Rights Under International Law from Charity to Human Rights (Oxon: Routledge, 2017), hlm. 6. 
khususnya hak atas pekerjaan dan hak sosial, ekonomi dan budaya (EKOSOB), dan konsekuensinya terhadap penyandang disabilitas. Bagian berikutnya mendiskusikan tantangan dalam merealisasikan hak atas pekerjaan bagi penyandang disabilitas di sektor publik, disusul pembahasan mengenai pendekatan kebijakan afirmatif terhadap penyandang disabilitas. Artikel ini berpendapat bahwa kebijakan afirmatif pada kenyataannya tidak memberikan peluang yang setara bagi penyandang disabilitas karena formasi khusus dan persyaratan medis menghambat para penyandang disabilitas untuk melamar pada bidang pekerjaan yang sesuai dengan minat dan latar belakang pendidikannya.

\section{B. Model Medis dan Amal dalam UU Penyandang Cacat}

Undang-Undang Nomor 4 Tahun 1997 tentang Penyandang Cacat (UU Penyandang Cacat) diperkenalkan di akhir periode pemerintahan Soeharto yang memandang para penyandang disabilitas sebagai individu dengan kondisi kelainan fisik atau mental yang berpotensi menimbulkan hambatan terhadap kapasitas mereka dalam menjalani kehidupan sehari-hari. UU Penyandang Cacat menginstitusionalisasikan pandangan mapan dan historis yang hidup di masyarakat Indonesia yang menganggap kondisi disabilitas sebagai 'abnormalitas' fisik atau mental yang menyebabkan penderitanya tidak memiliki kesempatan yang sama seperti warga negara 'normal' lain untuk meningkatkan kesejahteraan selain menjadi penerima pasif kedermawanan negara. Pengertian ini diambil dari model disabilitas medis di mana keterbatasan fisik atau mental dipandang sebagai suatu penderitaan dan gejala patologis yang memerlukan perawatan klinis. ${ }^{10}$ Fungsi utama UU Penyandang Cacat bukan untuk menciptakan hak-hak individu yang dapat ditindaklanjuti, melainkan untuk menetapkan kondisi di mana pendidikan, bantuan sosial dan rehabilitasi akan diberikan oleh negara kepada para penyandang

10 Ron McCallum, "The United Nations Convention on the Rights of Persons with Disabilities: Some Reflection”, Sydney Law School Legal Studies Research Paper, 10, 30 (2010), hlm. 4. 
disabilitas. ${ }^{11} \mathrm{UU}$ ini memuat katalog hak dan mekanisme penegakan yang sangat dibatasi oleh persyaratan-persyaratan medis tertentu. Pasal 13 UU Penyandang Cacat menyatakan "setiap penyandang cacat mempunyai kesempatan yang sama untuk mendapatkan pekerjaan sesuai dengan jenis dan derajat kecacatannya." Demikian pula, Pasal 14 memberikan suatu kewajiban kepada perusahaan untuk memberikan "kesempatan atau perlakuan sama kepada penyandang cacat dengan mempekerjakan mereka sesuai dengan jenis dan derajat kecacatan, pendidikan dan kemampuannya yang disesuaikan dengan jumlah karyawan atau kualifikasi perusahaan.” Kendati tidak menetapkan proposisi minimum bagi keterlibatan penyandang disabilitas di suatu bidang pekerjaan, Peraturan Pemerintah Nomor 43 Tahun 1998 tentang Upaya Peningkatan Kesejahteraan Sosial Penyandang Cacat memperluas ketentuan UU Penyandang Cacat dengan menetapkan bahwa perusahaan negara dan swasta harus mempekerjakan satu penyandang disabilitas untuk setiap 100 orang karyawan.

Terlepas dari klaim terhadap Pasal ini sebagai tindakan afirmatif yang menjamin kesempatan bagi para penyandang disabilitas untuk mendapat pekerjaan, ketentuan beban persyaratan seperti kriteria jenis dan derajat kecacatan, tidak diragukan lagi, jelas memberikan hambatan signifikan untuk merealisasikan partisipasi penyandang disabilitas secara optimal. Berdasarkan UU ini, penyandang disabilitas tidak diperlakukan sebagai subjek hukum yang otonom yang mampu menentukan tindakannya sendiri berdasarkan kebebasan dan hak yang dimilikinya, melainkan sebagai objek dari suatu kebijakan yang diturunkan dari kekuasaan negara. Moertiningsih, dkk. misalnya, menemukan bahwa pemerintah gagal menerapkan kebijakan kuota sebagian karena pembuat kebijakan dan calon pemberi kerja melihat tingkat partisipasi penyandang disabilitas dalam lingkungan kerja sebagai formalitas belaka. ${ }^{12}$ Sistem pendidikan di Indonesia juga

11 Nicola Edwards, "Disability Rights in Indonesia? Problems with Ratification of the United Nations Convention on the Rights of Persons with Disabilites", Australian Journal of Asian Law, 15, 1 (2014), hlm. 4.

12 Sri Moertiningsih Adioetomo, dkk., Person with Disabilities in Indonesia Empirical Facts and Implications for Social Protection Policies (Jakarta Pusat: TNP2K, 2014), hlm. 27. 
mempengaruhi pembentukan segregasi sosial yang memisahkan sekolah antara siswa non-disabilitas dan siswa disabilitas dengan perlakuan khusus. Sistem pemisahan semacam ini pada gilirannya menghambat para penyandang disabilitas untuk memperoleh pekerjaan yang persyaratannya berada di atas kualifikasi pendidikan khusus.

Selain itu, UU ini bersifat paternalistik sejalan dengan karakteristik otoriterisme Soeharto karena memosisikan hubungan antara negara dan penyandang disabilitas secara top-down di mana pihak penyandang disabilitas dipandang sebagai penerima pasif bantuan amal Pemerintah. Di bawah UU Penyandang Cacat, rezim Orde Baru berusaha menekan kepentingan sosial dan politik yang mungkin berpotensi menganggu stabilitas rezim, termasuk kepentingan para penyandang disabilitas untuk membangun otonomi untuk merealisasikan hak EKOSOB mereka sebagai warga negara. ${ }^{13} \mathrm{Di}$ samping itu, sebagai negara dengan mayoritas muslim terbesar di dunia, interpretasi disabilitas fisik atau mental sebagai tragedi individu memainkan peran penting dalam membentuk kebijakan yang terkait dengan pemenuhan hak penyandang disabilitas. ${ }^{14}$ Menurut Thohari, munculnya istilah 'cacat' berawal dari stigma dan karma dalam masyarakat Jawa yang memandang kondisi disabilitas sebagai akibat dari tindakan dosa atau peristiwa magis yang menentukan individu dengan keterbatasan dinilai tidak otentik menjadi manusia. ${ }^{15}$ Fakih

13 Wardana dan Dewi, “Moving Away from Paternalism”, hlm. 190.

14 Gagasan ini dikenal dengan model disabilitas spiritual yang dapat ditemukan dalam banyak tatanan masyarakat Asia. Seorang penyandang disabilitas dalam masyarakat dipercaya dapat memberikan pelajaran terhadap orang lain agar menghindari perbuatan yang dilarang oleh agama dan mendorong setiap masyarakat untuk meningkatkan keimanan masingmasing. Dalam banyak kasus, persepsi ini mendorong masyarakat untuk mengucilkan para penyandang disabilitas dengan mengisolasi, memasung atau mengumpulkan para penyandang disabilitas atau penderita gangguan jiwa pada satu tempat. Mengenai model disabilitas ini, lihat M. Miles, "Disability on a Different Model: Glimpses of an Asian Heritage", Disability and Society, 15, 4 (2000): 603-18.

15 Slamet Thohari, Contesting Conceptions of Disability in Javanese Society After the Soeharto Regime: the Case of Yogyakarta Indonesia (Tesis, University of Hawaii, Hawaii, 2011), hlm. 5. 
mengkritik bahasa yang direproduksi oleh kebijakan nasional terhadap labelisasi cacat bermasalah karena menciptakan persepsi negatif yang berujung marjinalisasi. ${ }^{16}$ Ironisnya, prasangka atau stereotip negatif terhadap para penyandang disabilitas ini berjalan bersamaan dengan rendahnya pemahaman birokrat dan politisi terhadap kondisi dan hambatan yang dihadapi para penyandang disabilitas. ${ }^{17}$

UU Penyandang Cacat, karenanya, memiliki keterbatasan dalam mempromosikan HAM dan telah dikritik karena tidak sesuai dengan model disabilitas sosial yang diadopsi CRPD. Tidak ada kejelasan tentang pihak mana yang harus memenuhi kewajiban untuk melindungi hak-hak penyandang disabilitas. Bahkan, banyak gerakan disabilitas pasca Orde Baru kini menentang dan menolak penggunaan istilah 'cacat' yang mengandung konotasi negatif bagi para penyadang disabilitas sebagai kelompok sosial yang tidak berdaya dan memerlukan pertolongan dari lembaga amal dengan penanganan spesial. ${ }^{18}$ Ini pada gilirannya menyebabkan lahirnya persepsi inferior terhadap para penyandang disabilitas sebagai warga negara kelas dua dan menganggap kelainan pada tubuh seperti kerusakan yang ada pada benda-benda mati. ${ }^{19}$ Dengan demikian keputusan

16 Mansour Fakih, "The Role of Non-Governmental Organization in Social Transformation: a Participatory Inquiry in Indonesia" (Disertasi, University of Massachusetts, Boston, 1996).

17 Miles, "Disability on a Different Model", hlm. 605.

18 Edwards, "Disability Rights in Indonesia?", hlm. 2.

19 Kekuasaan politik Indonesia sangat dipengaruhi oleh budaya paternalistik yang menjunjung tinggi kehalusan atau eufimisme bahasa. Ada fase besar dalam penggunaan istilah yang dilekatkan pada penyandang disabilitas. Pertama, pada periode otoritarianisme demokrasi terpimpin(1959-1965) dan era Orde Baru (1966-1998). Pada 1960an, Soekarno mulai menghilangkan penggunaan istilah cacat dengan memperkenalkan istilah baru: orang yang kekurangan dalam aspek jasmani dan rohani yang sangat dipengaruhi oleh persepsi budaya Jawa yang eufimis. Istilah-istilah penghalusan ini muncul dalamberbagaiproduklegislasisepertigelandangan(homeless)digantidengan tunawisma, pelacur diganti dengan tunasusila, gangguan pendengaran diganti dengan tunarungu dan sebagainya. Namun pada era Orde Baru, istilah cacat kembali digunakan dan dikaitkan dengan ketidakutuhan (impairment atau penurunan nilai) dan ketidakmampuan bertahan hidup atau tergantung pada orang lain. Istilah yang digunakan secara khusus diciptakan oleh kalangan elite melalui produk hukum dan kemudian di 
meratifikasi CRPD membuat UU Penyandang Cacat tidak dapat direkonsiliasi dengan pemahaman teoritis baru tentang disabilitas yang membuat pendapat bahwa posisi UU Penyandang Cacat adalah saling melengkapi implementasi CRPD di tingkat domestik menjadi bermasalah.

\section{Kerangka HAM: Hak Ekonomi, Sosial dan Budaya (EKOSOB) dan Hak atas Pekerjaan}

\section{Perlindungan Konstitusional terhadap Penyandang Disabilitas}

Salah satu perubahan menonjol yang berkaitan dengan perlindungan hak penyandang disabilitas adalah perubahan sistem ketatanegaraan setelah berakhirnya rezim Soeharto. Kejatuhan Orde Baru membuka peluang bagi reformasi hukum untuk memasukkan hukum HAM sebagai bagian dari produk hukum domestik. Bahasa universal HAM yang secara politik beresiko di bawah Soeharto, kini menjadi katalisator untuk mengadvokasi hak para penyandang disabilitas dalam proses pembentukan kebijakan publik. ${ }^{20}$

Undang-Undang Nomor 39 Tahun 1999 tentang Hak Asasi Manusia (UU HAM) yang diadopsi pada masa pemerintahan BJ. Habibie menekankan bahwa setiap orang memiliki HAM dan kebebasan dasar baik dalam kehidupan individu dan kolektif di bidang politik, ekonomi, hukum, sosial dan aspek kehidupan lainnya. Secara umum, kemunculan UU ini tidak bisa dilepaskan dari praktikpraktik otoritarian yang diarahkan untuk menciptakan lingkungan dan kondisi sipil dan politik yang kondusif bagi gerakan sosial baru. ${ }^{21}$

terima oleh populasi masyarakat secara umum yang menanggapnya benar secara politis. Kedua, periode pasca reformasi 1998. Selama periode ini kelas elite dan gerakan sosial di tingkat akar rumput mencai terminologi yang lebih inklusif seperti perluasan penggunaan istilah 'difabel' atau different ability (memiliki kemampuan berbeda), meskipun masyarakat awam pada umumnya masih menggunakan terminologi lama. Lihat Suharto Suharto, Pim Kuipers, dan Pat Dorsett, "Disability Terminology and the Emergence of Diffability in Indonesia”, Disability and Society, 31, 5 (2016), hlm. 696-98.

20 Wardana dan Dewi, "Moving Away from Paternalism", hlm. 176.

21 Irwanto dan Slamet Thohari, "Understanding CRPD Implementation in Indonesia”, dalam Making Disability Rights Real in Southeast Asia Impelementing 
Meskipun telah memasukkan beberapa preseden model disabilitas sosial, sebagian besar pengaturan hak-hak penyandang disabilitas dalam UU HAM tetap dipengaruhi oleh model disabilitas medis yang dianut UU Penyandang Cacat. Ini memperkenalkan apa yang disebut sebagai kelompok masyarakat yang rentan (vunerable groups) yang memerlukan perlindungan khusus [Pasal 5 ayat (3)]. Selain hakhak yang berlaku untuk seluruh warga negara, beberapa Pasal dalam UU tersebut secara spesifik menyebut 'orang cacat' (khususnya anak) sebagai subjek hukum yang memiliki hak untuk mendapat perlakuan khusus. Pasal ini didasarkan pada the Convention on the Rights of the Child 1989 yang telah diratifikasi Indonesia pada 1990 yang 'menetapkan serangkaian kewajiban yang dirancang untuk memastikan anak-anak penyandang disabilitas menerima perawatan khusus sehubungan dengan kebutuhan khusus mereka dengan maksud untuk mencapai integrasi sosial yang sepenuhnya. ${ }^{22}$ Namun, UU HAM bertentangan dengan model sosial yang ditekankan CRPD sehingga menciptakan kerangka kerja yang terbatas dan jauh di bawah standar HAM internasional. ${ }^{23}$ Terlepas dari beberapa kritik terhadap penggunaan terminologi 'cacat' dalam UU HAM, ${ }^{24}$ reformasi hukum hak ini menawarkan peluang untuk memperluas hak-hak penyandang disabilitas melalui kebijakan publik.

Pengadopsian UU HAM juga dibarengi dengan perubahan Undang-Undang Dasar Negara Republik Indonesia Tahun 1945

the UN Convention on the Rights of Persons with Disabilities in ASEAN, ed. Derrick L. Cogburn and Tina Kempin Reuter (London: Lexington Books, 2017), hlm. 91-117.

22 Rosemary Kayess dan Phillip French, "Out of Darkness into Light? Introducing the Convention on the Rights of Persons with Disabilites”, Human Rights Law Review, 8, 1 (2008), hlm. 12.

23 Mengenai evaluasi terhadap hal ini lihat Nicola Colbran, Access to Justice Persons with Disabilites in Indonesia (Background Assessment Report, AusAID, 2010), hlm. 13-15.

24 Kritik gerakan disabilitas dan akademisi hukum misalnya ditujukan pada pengertian diskriminasi dalam Pasal 1 ayat (3) yang tidak memuat pengertian diskriminasi berdasarkan kondisi disabilitas yang ada pada penyandang. Mengenai hal ini lihat Fajri Nursyamsi, dkk., Kerangka Hukum Disabilitas di Indonesia Menuju Indonesia Ramah Disabilitas (Jakarta: Pusat Studi Hukum dan Kebijakan Indonesia, 2015). 
(UUD 1945) yang memasukkan seperangkat instrumen HAM secara komprehensif. Meskipun konstitusi tidak memiliki referensi khusus untuk para penyandang disabilitas, pernyataan-pernyataan yang berkaitan dengan HAM di dalamnya jelas mempromosikan prinsip non-diskriminasi, kesetaraan dan perlakuan yang sama di hadapan hukum sebagaimana yang dianut CRPD. ${ }^{25}$ Amandemen kedua menambahkan Bab baru yang sebagian besar didasarkan pada model Deklarasi HAM meliputi hak sipil, politik, sosial, ekonomi dan kebudayaan. Pasal 23 ayat (1) Deklarasi Universal HAM misalnya menjamin 'setiap orang berhak atas pekerjaan, berhak dengan bebas memilih pekerjaan, berhak atas syarat-syarat perburuhan yang adil dan menguntungkan serta berhak atas perlindungan dari pengangguran.' Di antara beberapa Pasal konstitusi yang didasarkan pada Deklarasi ini dan juga berkaitan dengan hak-hak penyandang disabilitas adalah Pasal 28A yang memastikan hak untuk hidup dan mempertahankan kehidupan dan Pasal 28I ayat (2) yang melindungi individu dari perlakuan diskriminatif atas dasar apapun. Selain itu, Pasal $28 \mathrm{H}$ ayat (2) menyebutkan bahwa setiap orang berhak mendapat kemudahan dan perlakuan khusus untuk memperoleh kesempatan dan manfaat yang sama untuk mencapai kesetaraan dan keadilan yang mencerminkan tindakan afirmatif terhadap penyandang disabilitas. ${ }^{26}$ Dalam konteks hak atas pekerjaan, Pasal 27 ayat (2) menjamin bahwa setiap warga negara berhak atas pekerjaan dan penghidupan yang layak bagi kemanusiaan. Demikian pula, Pasal 28E ayat (1) menyatakan bahwa setiap orang berhak memeluk agama dan beribadat menurut agamanya, memilih pendidikan dan pengajaran, memilih pekerjaan, memilih kewarganegaraan, memilih tempat tinggal di wilayah negara dan meninggalkannya, serta berhak kembali. Seluruh perubahan di tingkat konstitusi dimaksudkan untuk menghilangkan hambatan konstitusional dan legal-institusional yang merintangi lahirnya kondisi politik yang lebih egaliter sebagai prasyarat untuk mengartikulasikan pemenuhan hak-hak penyandang

25 Colbran, Access to Justice Persons, hlm. 14.

26 Colbran, Access to Justice Persons, hlm. 14. 
disabilitas. $^{27}$

Kodifikasi instrumen HAM internasional dan prinsip supremasi hukum (rule of law) ke dalam dokumen Konstitusi, dengan demikian dipandang sebagai titik awal bagi surutnya tradisi paternalisme Soeharto yang mengenyampingkan hak-hak penyandang disabilitas. ${ }^{28}$ Indonesia juga telah mereformasi sistem ketatanegaraan dengan memperkenalkan lembaga Mahkamah Konstitusi yang memungkinkan gerakan-gerakan disabilitas mengajukan keberatan terhadap produk legislasi undang-undang yang mungkin akan merugikan kepentingan mereka. Di samping itu, berbagai instrumen HAM internasional yang sangat luas telah ditambahkan sejak perubahan Konstitusi periode 1999-2002 untuk menunjang pemenuhan hak-hak penyandang disabilitas. Pada 2005 misalnya, Indonesia meratifikasi International Covenant on Economic, Social and Cultural Rights yang dipandang sangat penting dalam upaya memajukan pemenuhan hak-hak EKOSOB penyandang disabilitas. ${ }^{29}$ Konvensi ini memuat 31 Pasal yang memberikan hak untuk menentukan nasib sendiri, kebebasan dari diskriminasi berdasarkan ras, warna kulit, jenis kelamin, bahasa, agama, disabilitas dan pendapat

27 Wardana dan Dewi, "Moving Away from Paternalism”, hlm. 184.

28 Tradisi paternalisme dalam kebijakan yang berkaitan dengan disabilitas juga berhubungan dengan pandangan integralistik yang mendominasi pemikiran konstitusi UUD 1945. Ini dapat ditemukan dalam beberapa pemikiran Soekarno, Soepomo dan Soeharto yang memandang bahwa negara semestinya didasarkan riwayat hukum dan lembaga sosial asli masyarakat adat yang bercorak komunitarian. Pandangan integralis mengasumsikan hubungan antara negara dan masyarakat sebagai hubungan keluarga dan karenanya bentuk-bentuk bantuan sosial dan rehabilitasi yang dilakukan oleh lembaga amal negara terhadap para penyandang disabilitas dapat menjadi alegori dari bentuk tanggung jawab bapak terhadap para anggota keluarganya. Mengenai pandangan negara integralis lihat Tim Lindsey, "Indonesia Devaluing Asian Values, Rewriting Rule of Law", Asian Discourses of Rule of Law Theories and Implementation of Rule of Law in Twelve Asian Countries, France and the US, ed. Randall Pereenboom (New York: Routledge, 2004), hlm. 281-316; Marsilam Simandjuntak, Pandangan Negara Integralistik (Jakarta: Penerbit Grafitti, 1994).

29 Lihat UU No 11 Tahun 2005 tentang Pengesahan International Covenant on Economic, Social and Cultural Rights (Kovenan Internasional tentang HakHak Ekonomi, Sosial dan Budaya [Hak EKOSOB]). 
politik, dan melindungi hak ekonomi seperti hak untuk bekerja, hak untuk berserikat, hak menerima jaminan sosial, hak untuk menerima pelayanan kesehatan fisik dan mental, hak atas pendidikan dan hak atas partisipasi dalam kehidupan budaya. ${ }^{30}$

Pasal 6 mengakui hak atas pekerjaan, termasuk hak setiap orang atas kesempatan untuk mencari nafkah melalui pekerjaan yang dipilih atau diterimanya secara bebas dan akan mengambillangkah yang tepat untuk melindungi hak ini. Pasal 7 mendorong pengakuan terhadap upah yang adil untuk semua pekerjaan tanpa pembedaan apapun, terutama pada pekerja perempuan, mendukung kondisi kerja yang aman dan sehat memberikan kesempatan untuk promosi jabatan dan melindungi hak pekerja untuk istirahat, menikmati hiburan dan insentif lainnya. Ratifikasi Kovenan Hak EKOSOB mengandung hak-hak yang mempromosikan kesetaraan substantif sangat penting sebagai panduan untuk menghapus ketidaksetaraan struktural yang menghalangi pemenuhan hak penyandang disabilitas. ${ }^{31}$

Pada waktu yang sama, Indonesia juga meratifikasi International Covenant on Civil and Political Rights yang memuat aspek-asepk kebebasan berpikir, berorganisasi atau berserikat, kepastian hukum dan kesetaraan didepan hukum dan hak atas privasi. ${ }^{32}$ Pasal 2 Konvensi ini mengharuskan negara-negara anggotanya untuk menghormati hak individu tanpa adanya diskriminasi dan mengadopsi berbagai langkah yang perlu dilakukan untuk melindungan kebebasan sipil dan politik. Dampak dari perubahan sosial dan politik semacam ini misalnya, dapat ditemukan dalam kebangkitan gerakan disabilitas untuk memajukan kepentingan mereka. ${ }^{33}$ Kovenan ini mengakui

30 Simon Butt dan Tim Lindsey, Indonesian Law (Oxford: Oxford University Press, 2018), hlm. 268.

31 Andrea Broderick, "Harmonisation and Cross-Fertilisation of SocioEconomic Rights in the Human Rights Treaty Bodies: Disability and the Reasonableness Review Case Study”, Laws, 38, 5 (2016), hlm. 14.

32 UU No 12 Tahun 2005 tentang Pengesahan International Covenant on Civil and Political Rights (Kovenan Internasional tentang Hak-Hak Sipil dan Politik).

33 Stephen Meyers, Valerie Karr, dan Victor Pineda, "Youth with Disabilities in Law and Civil Society: Exclusion and Inclusion in Public Policy and NGO Networks in Cambodia and Indonesia”, Disability and the Global South, 1, 1 
bahwa pemenuhan hak-hak yang dijamin Deklarasi Universal HAM 'hanya dapat dicapai apabila diciptakan kondisi di mana setiap orang dapat menikmati hak sipil dan politik dan juga hak EKOSOB. ${ }^{34}$ Meluasnya ruang ekspresi kebebasan politik dapat membuka partisipasi gerakan disabilitas untuk menyuarakan kebijakan-kebijakan progresif termasuk di bidang ketenagakerjaan. Perubahan ini memiliki dampak yang tidak dapat diabaikan dalam memaknai proses legislasi yang berkaitan dengan hak-hak disabilitas yang melahirkan desakan untuk meratifikasi CRPD dan pembentukan UU Penyandang Disabilitas yang mengantikan UU Penyandang Cacat yang usang. ${ }^{35}$

\section{CRPD dan Hak atas Pekerjaan}

Indonesia merupakan peserta aktif dalam isu-isu disabilitas di tingkat global dan termasuk sebagai salah satu negara generasi pertama yang menandatangani CRPD sejak kemunculannya pada 2006. Meskipun demikian, Indonesia harus menunggu sampai 2011 untuk meratifikasi CRPD melalui Undang-Undang Nomor 19 Tahun 2011 tentang Pengesahan Convention on the Rights of Persons with Disabilites. Di samping menyatakan berlakunya CRPD di Indonesia, UU tersebut menegaskan hak sipil dan politik, dan hak EKOSOB bagi penyandang disabilitas dan mengakui perlunya menindaklanjuti kewajiban hukum Indonesia untuk membentuk kerangka kerja hukum yang sama sekali baru dalam mengimplementasikan CRPD. Konvensi ini menekankan inklusi dan partisipasi para penyandang disabilitas dalam pendidikan dan ketenagakerjaan yang didukung oleh akomodasi dan aksesibilitas yang diperlukan untuk mewujudkan hak-hak ini. ${ }^{36}$

(2014), hlm. 6; Hendra Y. Agustian, "Redefining Disability in the Context of Masyarakat Madani an Indonesian Model of Inclusive Society", British Journal of Special Education, 43, 4 (2016), hlm. 325-461.

34 Lihat lampiran UU No 12 Tahun 2005 tentang Pengesahan International Covenant on Civil and Political Rights (Kovenan Internasional tentang Hak-Hak Sipil dan Politik).

35 Baca Komnas HAM RI, Marjinalisasi Hak Politik Penyandang Disabilitas (Jakarta Barat: Komnas HAM, 2011); dan Komnas HAM RI, Komentar Umum Kovenan Internasional Hak Sipil dan Politik dan Kovenan Internasional Hak Ekonomi Sosial dan Budaya (Jakarta: Komnas HAM, 2009).

36 Kayess dan French, "Out of Darkness into Light?”, hlm. 30. 
Alih-alih melihat disabilitas sebagai masalah yang bersifat medis dan individual, CRPD memusatkan perhatian pada aspek budaya, sosial, ekonomi dan politik, dan meneliti bagaimana hambatan dalam aspekaspek tersebut pada gilirannya menciptakan kondisi-kondisi yang tidak memanusiakan para penyandang disabilitas. Oleh karenanya, CRPD menekankan bahwa para penyandang disabilitas merupakan subjek hukum penyandang hak yang mampu memperjuangkan hakhaknya dan mampu membuat keputusan secara mandiri berdasarkan kebebasan sebagai bagian dari anggota masyarakat. ${ }^{37}$

Tujuan dari konvensi ini adalah untuk mempromosikan, melindungi, memastikan HAM, kesetaraan dan kebebasan yang mendasar yang dapat dinikmati oleh semua orang penyandang disabilitas dan untuk mempromosikan penghormatan terhadap martabat bawaan mereka. ${ }^{38}$ Dimasukkannya jaminan hak atas pekerjaan juga dimaksudkan untuk menegosiasikan minat banyak negara untuk mengentaskan kemiskinan yang dihadapi oleh para penyandang disabilitas diberbagai negara. Organisation for Economic Co-operation and Development (OECD) menunjukkan bahwa tingkat partisipasi penyandang disabilitas dalam dunia kerja kurang dari jumlah usia produktif penyandang disabilitas di seluruh dunia yang membuat mereka tidak dapat keluar dari belenggu kemiskinan. ${ }^{39}$ Para penyandang disabilitas kerap bekerja pada lingkungan atau kondisi kerja yang buruk, prospek promosi jabatan yang tidak menjanjikan dan umumnya ditempatkan dalam bidang pekerjaan yang bergaji rendah. ${ }^{40}$ Menurut WHO, ada beberapa hambatan umum yang

37 Irwanto, dkk., Analisis Situasi Penyandang Disabilitas di Indonesia: sebuah Desk Review (Jakarta: Pusat Kajian Disabilitas Fisip UI dan AusAID, 2010), hlm. 17.

38 Einat Albin, "Universalizing the Right to Work of Persons with Disabilities: An Equality and Dignity Based Approach", Hebrew University of Jerusalem Legal Studies Research Paper Series, 15, 9 (2015), hlm. 7.

39 Lihat Marco Fasciglione, "Article 27 of the CRPD and the Right of Inclusive Employment of People with Autism", dalam Protecting the Rights of People with Autism in the Fields of Education and Employment, ed. Valentina Della Fina dan Rachele Cera (London: Springer, 2015), hlm. 150.

40 Lihat Jeff D. Grischow, "I Nearly Lost my Work: Chance Encounters, Legal Empowerment and the Struggle for Disability Rights in Ghana", Disability 
dihadapi penyandang disabilitas yang kerap ditemukan di berbagai negara berpenghasilan rendah, seperti kurangnya aksesibilitas, kesalahpahaman di kalangan pemberi kerja atau rekan kerja, diskriminasi dalam lingkungan kerja, dan peraturan ketenagakerjaan atau peraturan penunjang lain yang tidak ramah terhadap penyandang disabilitas. ${ }^{41}$

Bahkan, situasi semacam ini bisa menjadi lebih buruk di negaranegara berkembang di mana lapangan kerja menjadi sangat langka dan diperebutkan oleh masyarakat secara umum. Para penyandang disabilitas di negara-negara berkembang sering menjadi korban kekerasan dan pelecehan seksual, dan hanya sedikit dari mereka yang memiliki akses keadilan dan memiliki pengetahuan tentang hak-hak mereka sebagaimana yang dijamin CRPD. ${ }^{42}$ WHO menemukan bahwa rumah tangga dengan penyandang disabilitas di negara-negara berkembang memiliki tingkat kemiskinan yang tinggi daripada mereka yang tidak memiliki anggota keluarga dengan disabilitas. Selain itu, kemiskinan dapat menyebabkan disabilitas melalui malnutrisi, perawatan kesehatan yang buruk dan kondisi kerja yang berbahaya dan pada saat yang sama, disabilitas dapat menyebabkan kemiskinan akibat hilangnya pekerjaan atau tidak adanya kesempatan untuk memperoleh pendidikan dan pekerjaan yang layak. ${ }^{43}$

and Society, 30, 1 (2015): 101-13.

41 WHO, World Disability Report(Genewa: WHO \& World Bank, 2011), hlm. 239.

42 Perbedaan antara kondisi sosial, ekonomi dan politik antara negara-negara Utara (global North) dan negara-negara Selatan (global South) menjadi salah satu sasaran utama studi hukum kritis disabilitas dalam memahami CRPD. Meekosha dan Soldatic misalnya mengkritik CRPD karena cenderung memfokuskan pada hambatan yang dirasakan oleh warga penyandang disabilitas di negara-negara industri maju. CRPD dipandang mengabaikan ketidaksetaraan antara negara maju dan berkembang di mana kondisi kemiskinan yang dialami penyandang disabilitas merupakan akibat dan warisan langsung proses kolonisasi bangsa, budaya paterinalisme dan globalisasi modal yang secara sistematis menyingkirkan para penyandang disabilitas keluar proses distribusi kesejahteraan. Mengenai hal ini lihat Helen Meekosha dan Karen Soldatic, "Human Rights and the Global South: the Case of Disability”, Third World Quarterly,38, 8 (2011): 1383-97.

43 Albin, "Universalizing the Right to Work", hlm. 6. 
Pasal 27 diadopsi untuk mengatasi masalah ini dengan menetapkan hak atas pekerjaan sebagai salah satu aspek esensial dalam CRPD dan menetapkan kerangka kerja hukum untuk diterapkan negara-negara anggota guna membangun kesempatan kerja yang sama tanpa diskriminasi. Ini memberikan pengakuan terhadap hak seperti hak atas kesempatan untuk mencari nafkah dengan pekerjaan yang dipilih atau diterima secara bebas di pasar tenaga kerja dan lingkungan kerja yang terbuka, inklusif dan dapat diakses oleh para penyandang disabilitas. Model sosial disabilitas menekankan prinsip pilihan bebas yang mengisyaratkan beberapa faktor pendukung untuk merealisasikan pilihan pekerjaan yang diminati. ${ }^{44}$ Karenanya tantangan bagi para pembuat hukum dan kebijakan tidak hanya untuk menciptakan dan menegakkan hak-hak dalam ketenagakerjaan yang setara, tetapi juga memfasilitasi jenis dan kondisi yang nyata bagi pasar tenaga kerja yang memungkinkan hak-hak penyandang disabiltias bisa dijalankan. ${ }^{45}$

\section{UU Penyandang Disabilitas}

Kendala utama yang dihadapi dalam mengimplementasikan CPRD sejak diratifikasi oleh Indonesia pada 2011 adalah tidak ada kerangka kerja hukum operasional yang sesuai dengan pendekatan model sosial disabilitas. UU Penyandang Cacat sangat tidak memadai untuk menjalankan pendekatan baru yang diperkenalkan CRPD yang menyebabkan ada tekanan luas untuk membentuk produk hukum baru. Dalam konteks inilah koalisi organisasi masyarakat sipil yang mempromosikan hak-hak penyandang disabilitas memainkan peran penting dalam proses reformasi hukum, mengambil inisiatif untuk menyusun RUU Penyandang Disabilitas pada 2013 yang melibatkan para penyandang disabilitas di seluruh Indonesia dan berhasil memasukkan RUU tersebut ke dalam agenda legislasi nasional satu

44 Lisa Waddington, Mark Priestley, dan Betul Yalcin, "Equality of Opportunity in Employment? Disability Rights and Active Labour Market Policies", dalam Routledge Handbook of Disability Law and Human Rights, ed. Peter Blanck dan Eilinoir Flynn (New York: Routledge, 2017), hlm. 73.

45 Waddington, dkk., "Equality of Opportunity in Employment?", hlm. 73. 
tahun berikutnya. ${ }^{46}$

UU Penyandang Disabilitas muncul sebagai tanggapan atas ratifikasi CRPD di mana Indonesia diwajibkan untuk melakukan penyesuaian terhadap kerangka hukum domestik, termasuk penyediaan aksesibilitas dan sistem kelembagaan disabilitas pada setiap sarana publik yang diselenggarakan oleh negara. ${ }^{47}$ Model disabilitas sosial yang ada di dalamnya mengakui bahwa para penyandang disabilitas adalah orang-orang yang secara ekonomi, politik, sosial dan kebudayaan tertindas oleh non-disabilitas yang memerlukan rekonsiliasi cara pandang untuk mencapai inklusivisme. UU ini memainkan peran penting dalam mempromosikan HAM karena menetapkan kerangka kerja untuk merealisasikan pemenuhan hak atas pekerjaan bagi penyandang disabilitas. Mirip dengan tujuan yang dikemukakan CRPD, UU ini bertujuan antara lain memajukan perlindungan dan pemenuhan HAM, melindungi martabat yang melekat pada setiap penyandang disabilitas, mendorong peningkatan taraf kehidupan secara lahir dan batin, melindungi penyandang disabilitas dari pelecehan, eksploitasi dan diskriminasi, dan memastikan pengembangan diri sesuai bakat dan minat yang dimiliki serta berkontribusi secara optimal, aman dan leluasa dalam kehidupan.

UU Penyandang Disabilitas mengadopsi terminologi yang dirancang CRPD di mana penyandang disabilitas adalah 'mereka yang memiliki gangguan fisik, mental, intelektual atau sensorik jangka panjang yang dalam interaksi dengan berbagai hambatan

46 Desakan untuk mengesahkan UU Penyandang Disabilitas semakin menguat dari koalisi masyarakat sipil akibat ratifikasi CRPD pada 2011. Meskipun demikian, PusatStudi Hukum dan Kebijakan Publik menilai sejak2013 ketika pertama kali RUU Penyandang Disabilitas masuk dalam prioritas legislasi, DPR dinilai belum melibatkan masyarakat. Pada 2015, versi final naskah akademik dan rancangan undang-undang menerima banyak kritik dari organisasi masyarakat sipil dengan perbaikan yang hampir menyeluruh di dalamnya. Emma Blomkamp, dkk., Understanding Policymaking in Indonesia: In Search of a Policy Cycle (Jakarta: PSHK \& University of Melbourne, 2017), hlm. 22.

47 DPR RI, Naskah Akademik Rancangan Undang-Undang tentang Penyandang Disabilitas (Jakarta: DPR RI, tanpa tahun), hlm. 16. 
dapat menghalangi mereka sepenuhnya dan partisipasi efektif dalam masyarakat atas dasar kesetaraan dengan orang lain.' Ini memperkenalkan model sosial disabilitas di mana disabilitas dipahami bukanlah sebagai sifat bawaan, melainkan disebabkan oleh hambatan sosial yang mencegah interaksi penuh orang yang hidup dengan keterbatasan fisik, sensorik, intelektual, atau psikologis. ${ }^{48}$ Pasal 11 UU ini mengakomodasi hak atas pekerjaan, kewirausahaan dan koperasi bagi penyandang disabilitas meliputi, inter allia: memperoleh pekerjaan yang diselenggarakan oleh pemerintah, pemerintah Daerah, atau swasta tanpa diskriminasi; memperoleh upah yang sama dengan tenaga kerja yang bukan penyandang disabilitas dalam jenis pekerjaan dan tanggung jawab yang sama; memperoleh akomodasi yang layak dalam pekerjaan; tidak diberhentikan karena alasan disabilitas; mendapatkan program kembali bekerja; penempatan kerja yang adil, proporsional, dan bermartabat; memperoleh kesempatan dalam mengembangkan jenjang karier serta segala hak normatif yang melekat di dalamnya; dan memajukan usaha, memiliki pekerjaan sendiri, wiraswasta, pengembangan koperasi, dan memulai usaha sendiri.

Pasal 28 sampai 39 mengatur kewajiban pemerintah dan pemerintah daerah untuk menjamin dan melindungi hak penyandang disabilitas sebagai subjek hukum untuk melakukan tindakan hukum yang sama dengan orang lain. Pemerintah dan pemerintah daerah bahkan harus menyediakan beasiswa bagi siswa penyandang disabilitas yang berprestasi tinggi yang orang tuanya tidak dapat membayar pendidikan mereka, dan secara finansial mendukung semua siswa penyandang disabilitas yang orang tuanya tidak dapat membiayai pendidikan mereka. ${ }^{49}$ Berbeda dari hak untuk rehabilitasi yang diperkenalkan UU Penyandang Cacat, rehabilitasi dalam konteks UU Penyandang Disabilitas tidak dipandang sebagai proyek yang dipaksakan oleh negara untuk 'memperbaiki' penyandang disabilitas, tetapi sebagai hak yang mengakui martabat individu dan

48 Butt dan Lindsey, Indonesian Law, hlm. 267.

49 Butt dan Lindsey, Indonesian Law, hlm. 268. 
kapasitas pengambilan keputusan dari orang yang bersangkutan. ${ }^{50}$ Pengaturan semacam ini mencerminkan semangat demokratisasi di mana para penyandang disabilitas dapat berpartisipasi aktif dalam proses pembentukan hukum dan mengorganisasi diriuntuk menentut kebijakan publik yang berhubungan dengan nasib mereka. ${ }^{51}$

Senada dengan UU Penyandang Disabilitas, Undang-Undang Nomor 13 Tahun 2003 tentang Ketenagakerjaan (UU Ketenagakerjaan) memberikan perlindungan terhadap hak atas pekerjaan bagi penyandang disabilitas meskipun dalam penggunaan istilah yang sejalan dengan UU Penyandang Cacat. Pasal 9 UU Ketenagakerjaan menyatakan, "pelatihan kerja bagi tenaga kerja penyandang cacat dilaksanakan dengan memperhatikan jenis, derajat kecacatan, dan kemampuan tenaga kerja penyandang cacat yang bersangkutan.” Menurut Lamichhane, program pelatihan harus mempertimbangkan keterampilan mana yang mudah dipasarkan, dimulai dengan keaksaraan dasar tetapi berorientasi pada pengembangan keterampilan yang akan penting bagi situasi ekonomi. ${ }^{52}$ Pemerintah juga harus mengembangkan pendidikan alternatif seperti pelatihan kejuruan dan program pengembangan keterampilan lainnya dengan status setara di pasar tenaga kerja. ${ }^{53}$ Pasal 153 melarang melakukan pemecatan terhadap "pekerja/buruh dalam keadaan cacat tetap, sakit akibat kecelakaan kerja, atau sakit karena hubungan kerja yang menurut surat keterangan dokter yang jangka waktu penyembuhannya belum dapat dipastikan." Perlindungan dalam konteks UU ini harus dilakukan dalam bentuk penyediaan aksesibilitas, penyediaan perangkat untuk melindungi diri sendiri sesuai dengan jenis dan tingkat disabilitas seseorang. ${ }^{54}$

50 Wardana dan Dewi, "Moving Away from Paternalism”, hlm. 189.

51 Hastuti, dkk., Kendala Mewujudkan Pembangunan Inklusif terhadap Penyandang Disabilitas, ed. Dhania Putri Sarahtika dan Liza Hadiz (Jakarta: SMERU Research Institute, 2019).

52 Kamal Lamichhane, Disability, Education and Employment in Developing Countries From Charity to Investment (New Delhi: Cambridge University Press, 2015), hlm. 64.

53 Lamichhane, Disability, Education and Employment, hlm. 64.

54 Adioetomo, dkk., Person with Disabilities in Indonesia, hlm. 28. 
Meskipun dipuji sebagai salah satu reformasi berbasis hak, Indonesia masih berurusan dengan implementasi hak-hak disabilitas yang lemah karena berbagai peraturan tidak sejalan dengan CRPD. UU Ketenagakerjaan secara implisit tidak melarang pembatalan rekrutmen atau pemutusan hubungan kerja yang dilakukan oleh pemberi kerja akibat kondisi 'kecacatan’ (Pasal 172). Kurangnya urgensi dalam mengimplementasikan UU ini juga diperkuat oleh minimnya data dan informasi tentang besarnya masalah dan situasi para penyandang disabilitas, ${ }^{55}$ baik untuk pembuat kebijakan (pengawas ketenagakerjaan di lapangan) dan calon pemberi kerja. ${ }^{56}$ Penelitian baru-baru ini menyebutkan bahwa dalam dunia kerja penyandang disabilitas masih menghadapi masalah, di antaranya model pembayaran pekerjaan yang bersifat harian, mingguan atau pembayaran berdasarkan luaran kerja, minimnya perlindungan asuransi kesehatan dan kecelakaan kerja, dan upah yang lebih rendah dari rata-rata orang pada umumnya. ${ }^{57}$

Dalam konteks rekrutmen ketenagakerjaan, kriteria atau syarat kesehatan jasmani dan rohani yang umumnya dibebankan oleh pemberi kerja kepada calon pelamar penyandang disabilitas pada akhirnya kerap menghalangi penyandang disabilitas untuk memperoleh pekerjaan yang mereka inginkan. Sampai dengan saat ini tidak ada mekanisme aduan yang dapat menyelesaikan secara efektif kasus perampasan hak atas pekerjaan yang dialami penyandang disabilitas, kecuali melalui Komnas HAM yang akan diteruskan ke instansi-instansi terkait. Menurut Colbran, Komnas HAM sering mendapat pengaduan kasus diskriminasi terhadap penyandang disabilitas seperti kasus pemecatan dan diskriminasi proses rekrutmen pegawai negeri sipil (PNS) di beberapa daerah yang sulit diselesai-

55 Kesulitan untuk mengidentifikasi jumlah kuota yang tepat untuk mewujudkan diversitas ketenagakerjaan di masing-masing daerah akan sangat tergantung pada jumlah populasi yang mungkin sangat berbeda antara satu daerah dengan daerah yang lain.

56 Adioetomo, dkk., Person with Disabilities in Indonesia, hlm. 27.

57 Lembaga Penyelidikan Ekonomi dan Masyarakat FE UI, Laporan Akhir Memetakan Penyandang Disabilitas di Pasar Tenaga Kerja Indonesia (Jakarta: International Labour Organization [ILO], 2017), hlm. 21-24. 
kan. ${ }^{58}$ Penyandang disabilitas masih menghadapi diskriminasi dalam bidang pendidikan dan kesehatan yang menyebabkan mereka kerap gagal mengikuti tes untuk mendapatkan pekerjaan atau mengikuti ujian yang lebih tinggi. ${ }^{59}$ Stigmatisasi terhadap penyandang disabilitas sebagai kelompok masyarakat yang memiliki produktivitas yang rendah pada gilirannya mempengaruhi penilaian pemberi kerja agar enggan menerima calon pegawai dengan kondisi disabilitas tertentu. Sikap pemberi kerja dan rekan kerja jelas penting dalam membentuk hambatan sosial untuk menciptakan kesempatan kerja yang setara. ${ }^{60}$

\section{Hak Atas Pekerjaan di Sektor Publik dalam UU Aparatur Sipil Negara}

Undang-Undang Nomor 5 tahun 2014 tentang Aparatur Sipil Negara (UU ASN) merupakan UU yang memperkenalkan semangat reformasi birokrasi yang bertujuan untuk membentuk PNS yang profesional dan berkompetensi sesuai bidang keahliannya masingmasing. UU ini merupakan respons terhadap keluhan masyarakat atas buruknya kredibilitas lembaga publik, birokrasi yang korup dan budaya klientelisme yang tumbuh di institusi-institusi negara yang memengaruhi praktik rekrutmen, promosi jabatan dan berbagai aspek lain yang berhubungan dengan sumber daya manusia. ${ }^{61}$ Secara teoretis, UU ASN menerapkan pemikiran manajemen sumber daya manusia strategis yang lebih baru yang memandang karyawan

58 Beberapa kasus yang pernah ditangani Komnas HAM yang berhubungan dengan diskriminasi terhadap penyandang disabilitas adalah pemecatan PNS di Sumatera Barat, pengusiran paksa di pusat perbelanjaan di Jakarta, keluhan layanan pendidikan, diskriminasi proses rekruitmen CPNS di Jawa Tengah dan Jawa Barat, dan penghinaan terhadap penyandang disabilitas di acara komedi di Global TV. Colbran, Access to Justice Persons, hlm. 26.

59 Komnas HAM, Mendorong Pengesahan "Optional Protocol to the Convention on the Rights of Persons with Disabilities" (OP CRPD) dalam Rangka Pemenuhan Hak Asasi Manusia Penyandang Disabilitas (Jakarta Barat: Komnas HAM, 2016), hlm. 4-5.

60 Waddington, dkk., "Equality of Opportunity in Employment?", hlm. 85.

61 Stein Kristianten dan Muhid Ramli, "Buying an Income: the Market for Civil Service Positions in Indonesia", Contemporary Southeast Asia, 28, 2 (2006): 207-33. 
sebagai aset terpenting dari suatu organisasi. Berdasarkan alasan ini, UU tersebut kemudian mensyaratkan penerapan prinsip prestasi dalam proses perekrutan, penempatan, promosi, dan pengupahan yang sistematis terhadap PNS. ${ }^{62}$ Oleh karena itu, pendekatan ini juga berlaku bagi calon PNS dengan disabilitas tertentu yang diseleksi melalui proses rekrutmen yang disesuaikan dengan kondisi disabilitas tertentu.

Tuntutan restrukturalisasi rekrutmen pada dasarnya merupakan bagian dari agenda reformasi hukum ASN yang lebih luas di mana budaya tidak terbuka dan transparan yang telah mengakar dalam proses rekruitmen PNS memiliki dampak signifikan terhadap penurunan kualitas sumber daya manusia. Upaya mereformasi kebijakan "rekrutmen ASN baik di tingkat pusat dan daerah sangat penting karena banyak birokrat masih ingin menduduki posisi elite" dengan imbalan atau upah yang diperoleh dengan cara-cara yang tidak sehat. ${ }^{63}$ Bidang ketenagakerjaan di sektor publik, baik dalam birokrasi maupun perusahaan negara, merupakan bidang profesi yang sejak lama diperebutkan para pencari kerja karena menawarkan stabilitas, priviledge dan kesejahteraan sosial yang berkelanjutan. Profesi ini berhubungan dengan pembentukan regulasi dan penyelenggaraan negara sehingga kebijakan-kebijakan yang berkaitan dengan hak atas pekerjaan bagi penyandang disabilitas akan sangat dipengaruhi oleh cara pandang dan persepsi penyelenggara negara terhadap kelompokkelompok terpinggirkan seperti penyandang disabilitas. Tindakan afirmatif melalui kuota akan memengaruhi cara lembaga publik untuk merekrut, memilih, memutuskan, mempromosikan atau menempatkan pengawai publik dengan disabilitas dalam bekerja.

Dalam konteks inilah, UU ASN berusaha mengakomodasi prinsip rekrutmen yang berbasis pada paradigma meritokrasi di mana ASN direkrut berdasarkan kualifikasi, kompetensi dan kinerja secara

62 Syarif Ali, "Indonesian Civil Service Management and Corruption”, Asia Pacific Fraud Journal, 4, 1 (2019), hlm. 19.

63 Erwan Agus Purwanto, Agus Pramusinto, dan Dwiyanto Indiahono, "Politics-Administration on the Dynamic Relations of Elected Officials and Bureaucracy in the Recruitment of Local Career Officials", Advances in Social Science, Education and Humanities Research, 191 (2018), hlm. 438. 
adil dan wajar dengan tanpa membedakan latar belakang politik, ras, warna kulit, agama, asal usul, jenis kelamin, status pernikahan, umur atau kondisi 'kecacatan.' Gagasan ini diakomodasi dalam konsep manajemen ASN yang dikelola sedemikian rupa untuk menghasilkan pegawai yang profesional, memiliki nilai dasar, etika profesi, bebas dari intervensi politik, bersih dari praktik korupsi kolusi dan nepotisme. Sistem prestasi dimaksudkan untuk memastikan integritas dan efektivitas layanan publik dengan pemilihan prosedur bahwa pegawai akan dilindungi dari campur tangan dan penyalahgunaan politik. $^{64}$

Pasal 58 memberikan mandat untuk pengadaan PNS yang diumumkan secara terbuka kepada masyarakat di mana setiap warga negara mempunyai kesempatan yang sama untuk melamar menjadi PNS setelah memenuhi persyaratan. Proses ini dilakukan melalui Badan Kepegawaian Negara yang dibentuk berdasarkan UU ASN untuk menyelenggarakan seleksi calon ASN. Rekrutmen harus terlebih dahulu dilakukan melalui tahap analisis pekerjaan dan persyaratan sebelum pengumuman rekruitmen dilakukan, dan untuk memungkinkan terpilihnya kandidat PNS yang terbaik, proses rekruitmen harus dilakukan secara adil dan terbuka. ${ }^{65}$ Dalam konteks inilah bidang ketenagakerjaan publik harus menjadi pemimpin yang mempromosikan kesempatan kerja yang setara bagi penyandang disabilitas yang dapat meningkatkan representasi keberagaman dan lingkungan kerja yang inklusif bagi penyandang disabilitas. ${ }^{66}$ Integrasi kerja para penyandang disabilitas sebenarnya adalah "proses interaksi yang dinamis di antara berbagai faktor, termasuk karakteristik individu, sifat pekerjaan, kondisi lingkungan kerja, serta

64 Fauzul Mubin dan Ali Roziqin, "Meritocracy of Bureaucracy in Indonesia”, International Journal of Social Science and Humanity, 8, 8 (2018), hlm. 242.

65 Projo Tjiptoherijanto, "Civil Service Reform in Indonesia: Culture and Institution Issues", Working Paper in Economics and Business, 2, 7 (2012), hlm. 5-6.

66 Elza Maharromova, "Disability Employment Policies within the Civil Service, Managing Diversity in the Civil Service", dalam UNDESAIIAS,Managing Diversity in the Civil Servic (Amsterdam: IOS Press, 2002), hlm. 92. 
ketersediaan akomodasi yang mendukung." 67

Namun, UU ini sayangnya tidak mengatur hal yang berhubungan dengan implementasi hak penyandang disabilitas untuk berpartisipasi dalam penyelenggaraan negara, kecuali melalui Pasal deklaratif di mana setiap warga negara, termasuk penyandang disabilitas memiliki kesempatan yang sama untuk melamar. Prasyarat yang dibebankan kepada calon pelamar yang juga berlaku bagi penyandang disabilitas antara lain harus memenuhi persyaratan: (a) lulus pendidikan dan pelatihan; dan (b) sehat jasmani dan rohani yang "disesuaikan dengan kebutuhan pelaksaaan pekerjaan”. Persyaratan semacam ini tidak sejalan dengan model disabilitas sosial yang diadopsi UU Penyandang Disabilitas. Alih-alih mendorong kesetaraan atas kesempatan kerja, persyaratan ini berpotensi mendiskriminasi para penyandang disabilitas karena dapat ditafsirkan bahwa para penyandang disabilitas hanya dapat melakukan pekerjaan pada bidang-bidang pekerjaan tertentu yang telah ditentukan atas dasar keterbatasan fisiknya. Ironisnya, "hal ini berlangsung tanpa banyak perdebatan karena komunitas penyandang disabilitas tidak mendapatkan informasi yang memadai tentang kebijakan ini." ${ }^{68}$

Potensi diskriminasi ini juga didukung oleh minimnya pengaturan proses rekrutmen penyandang disabilitas yang sejalan dengan CRPD dan UU Penyandang Disabilitas. Pada 2017 misalnya, Menteri Pendayagunaan Aparatur Negara dan Reformasi Birokrasi menerbitkan Permen PAN-RB Nomor 20 Tahun 2017 tentang Kriteria Penetapan Kebutuhan Pegawai Negeri Sipil dan Pelaksanaan Seleksi Calon Pegawai Negeri Sipil Tahun 2017 (Permen PAN-RB 2017) sebagai pedoman bagi Pemerintah Pusat dan Daerah untuk pengadaan PNS. Meskipun Peraturan ini memberikan kesempatan bagi penyandang disabilitas untuk mendaftar, menurut Nursyamsi jumlah kuota yang dibuka pada 2017 pada dasarnya hanya mencapai 0,44 persen dari total 37.138 formasi yang ada. Peraturan ini tidak

67 Katharina Vornholt, dkk., "Disability and Employment-Overview and Highlights", European Journal of Work and Organizational Psychology, 27, 1 (2018), hlm. 46.

68 Adioetomo, dkk., Person with Disabilities in Indonesia, hlm. 28. 
mengatur lebih lanjut persyaratan fisik dan mental sebagaimana yang diamanatkan UU ASN, sehingga dapat ditafsirkan bahwa persyaratan sepenuhnya tergantung pada masing-masing instansi. Pada 2018 pemerintah kembali memperbaiki ketentuan ini melalui PermenPANRB 2018, yang memperkenalkan formasi khusus untuk penyandang disabilitas. Peraturan ini menetapkan sejumlah persyaratan tingkat disabilitas yang disandang dan kualifikasi pendidikan yang disalurkan pada formasi khusus yang telah ditetapkan dan diverifikasi langsung secara medis oleh panitia. ${ }^{69}$ Konsep formasi khusus dimaksudkan untuk memperbaiki beberapa kekurangan dalam Permen PAN-RB 2017 yang belum mengakomodasi ketentuan tentang penyandang disabilitas. Di samping itu, formasi khusus dipromosikan sebagai bentuk kebijakan afirmasi yang mendorong para penyandang disabilitas untuk masuk pada prioritas-prioritas yang ditetapkan oleh pemerintah dengan tujuan mendorong secara cepat pemenuhan hak atas pekerjaan bagi penyandang disabilitas. ${ }^{70}$ Langkah ini diklaim sebagai upaya pemenuhan Pasal 27 huruf g CRPD yang mensyaratkan negara-negara anggotanya untuk mempekerjakan para Penyandang Disabilitas di sektor publik.

\section{E. Sistem Kuota sebagai Kebijakan Afirmatif?}

UU Penyandang Disabilitas mengadopsi pendekatan yang bergantung pada intervensi negara di pasar tenaga kerja untuk memperbaiki distribusi lapangan kerja bagi para penyandang disabilitas yang telah lama diabaikan. Ini didasarkan pada sistem kuota sebagai kebijakan afirmatif yang bertujuan untuk meningkatkan jumlah pekerja penyandang disabilitas yang kurang terwakili dan mengalami diskriminasi. ${ }^{71}$ Ketentuan ini merupakan pencapaian luar biasa dalam tata kelola layanan publik karena memberikan diskriminasi positif terhadap akses pekerjaan di sektor publik dan privat. Kuota

69 Lihat Poin F Lampiran Permen PAN-RB 2018.

70 Nursyamsi, "Formasi Khusus Disabilitas".

71 Patricia Thornton dan Neil Lunt, Employment for Disabled People Social Obligation or Individual Responsibility? (New York: Social Policy Research of University of York, 1995), hlm. 8. 
dimaksudkan untuk memperbaiki ketidaksempurnaan pasar tenaga kerja dan diskriminasi yang dapat meningkatkan peluang kerja di kalangan penyandang disabilitas. Pasal 53 mewajibkan Pemerintah, Pemerintah Daerah dan Badan Usaha Milik Negara (BUMN) mempekerjakan paling sedikit dua persen penyandang disabilitas dari jumlah pegawai atau pekerja dan satu persen penyandang disabilitas untuk perusahaan swasta. Kebijakan kuota diambil untuk memperbaiki kekurangan UU Penyandang Cacat yang tidak mengakomodasi semangat pemberdayaan para penyandang disabilitas. ${ }^{72}$ Ini dipandang sebagai win-win solution baik bagi pemerintah, masyarakat, maupun kalangan penyandang disabilitas sendiri. ${ }^{73}$

Pengadopsian sistem kuota ini sejalan dengan tren dalam tradisi hukum Eropa kontinental sebagai bentuk intervensi aktif negara melalui kewajiban sosial untuk memastikan tersedianya lapangan kerja bagi penyandang disabilitas. ${ }^{74}$ Ada dua jenis intervensi pasar tenaga kerja yang terdiri dari program aktif dan pasif terhadap penyandang disabilitas. Pertama, program aktif yang bertujuan untuk mengurangi pengangguran dengan meningkatkan akses pasar tenaga kerja. Ini dilakukan dengan meningkatkan kapasitas penyandang disabilitas melalui pendidikan untuk meningkatkan kualitas keahlian dan produktivitas mereka. ${ }^{75}$ Kedua, program pasif yang dilakukan

72 DPR RI, Risalah Rapat Kerja Komisi VIII DPR RI dengan Menteri Sosial dan Kementerian Lainnya terkait RUU Penyandang Disabilitas, Masa Sidang III 2015-2016, Ruang Rapat Komisi VIII DPR RI, 20/1/2016, hlm. 11.

73 Jazim Hamidi, "Perlindungan Hukum terhadap Disabilitas dalam Memenuhi Hak Mendapatkan Pendidikan dan Pekerjaan”, Jurnal Hukum Ius Quia Iustum, 32, 4 (2016), hlm. 662.

74 Pada akhir 1970an, kegagalan negara-negara kesejahteraan dalam merancang skema dukungan pendapatan dan layanan untuk penyandang disabilitas mulai memperluas pengaruh kebijakan penyandang disabilitas yang sejalan dengan krisis keuangan. Periode ini ditandai oleh menurunnya tren kebijakan ekonomi intervensionis seperti kebijakan keynesianis dan kebangkitan paradigma neoliberalisme di Inggris dan Amerika Serikat pada masa Margaret Thatcher dan Ronald Reagan yang menyebabkan pergeseran kebijakan ketenagakerjaan secara umum menuju orientasi mekanisme pasar. Mengenai hal ini lihat Fasciglione, "Article 27 of the CRPD”, hlm. 149.

75 Arie Rimmerman, Social Inclusion of People with Disabilities National and International Perspectives (New York: Cambridge University Press, 2013), 
dengan model disabilitas amal. Program ini menargetkan bentuk bantuan sosial seperti asuransi dan jaringan subsidi keluarga yang bertujuan untuk mengurangi kebutuhan finansial penyandang disabilitas. Banyak negara-negara berkembang, dengan keterbatasan kemampuan alokasi sumber daya, cenderung memilih program pertama karena membantu secara ekonomi dalam mengintegrasikan populasi yang rentan ke dalam pasar tenaga kerja. ${ }^{76}$

Perlakuan istimewa atau diskriminasi positif dalam bentuk kuota yang dianut Indonesia secara tegas mengambil program pasar tenaga kerja aktif yang menargetkan penghilangan hambatan hukum untuk pemerataan peluang bagi penyandang disabilitas. ${ }^{77}$ Asumsi di balik kebijakan kuota ialah bahwa tanpa kewajiban hukum untuk melibatkan para penyandang disabilitas yang dibebankan kepada pihak pemberi kerja, pemberi kerja akan berpotensi mengabaikan keberadaan para penyandang disabilitas. ${ }^{78}$ Gagasan ini sejalan dengan model sosial disabilitas di mana pemberi kerja harus menghilangkan hambatan dalam dunia kerja dan dengan demikian membentuk kondisi lingkungan kerja yang inklusif. WHO misalnya, melaporkan sekitar 15 persen penduduk dunia adalah penyandang disabilitas dan sekitar 70 persennya merupakan penduduk dalam usia produktif. ${ }^{79}$ Angka penyerapan tenaga kerja penyandang disabilitas yang rendah ini tercemin dalam jumlah penyandang disabilitas di Indonesia yang diperkirakan mencapai 21,9 juta dan separuh di antaranya tidak bekerja. Sebagian besar angkatan kerja penyandang disabilitas bekerja di sektor informal yang diperkirakan mencapai 64,93 persen dengan tingkat persebaran yang besar di wilayah pedesaan. ${ }^{80}$ Sedangkan lapangan pekerjaan dengan profesi kerah putih umumnya masih tersebar di beberapa kota besar di Indonesia yang memiliki aksesibilitas yang lebih responsif terhadap penyandang disabilitas. ${ }^{81}$

hlm. 84.

76 Rimmerman, Social Inclusion of People, hlm. 84.

77 Sargeant, dkk., "Disability Quotas: Past or Future Policy?”, hlm. 412.

78 WHO, World Disability Report, hlm. 243.

79 WHO, World Disability Report, hlm. 243.

80 LPEM, Laporan Akhir Memetakan Penyandang Disabilitas, hlm. 24.

81 Masalah ketimpangan partisipasi penyandang disabilitas yang terkonsentrasi 
Economic and Social Commision for Asia and the Pacific United Nations juga melaporkan banyak negara Asia berpenghasilan rendah cenderung membentuk karakter penyebaran pekerja penyandang disabilitas pada bidang pekerjaan yang rentan dan bersifat informal tanpa perlindungan asuransi dan stabilitas pendapatan. ${ }^{82}$ Menurut laporan Economic and Social Commision for Asia and the Pacific United Nations, Human Development Index penyandang disabilitas di Indonesia pada 2015-khususnya dalam hal indikator sosial ekonomiterhitung sangat rendah hanya mencapai 0,684 dengan ranking 108 dari 187 negara, yang menunjukkan kelompok penyandang disabilitas belum menjadi prioritas pembangunan nasional. ${ }^{83} \mathrm{SMERU}$ Institute melaporkan, tingkat partisipasi angkatan kerja pada 2018 hanya mencapai 55 persen untuk penyandang disabilitas ringan dan menengah, sedangkan penyandang disabilitas berat hanya mencapai 21 persen. $^{84}$ Mayoritas kelompok penyandang disabilitas yang bekerja di bidang formal bekerja pada sektor usaha jasa merupakan penyandang disabilitas yang memiliki latar belakang pendidikan sarjana (mencapai 35 persen). Menurut Kementerian Kesehatan, sekitar 16,5 persen dari angkatan kerja penyandang disabilitas berprofesi sebagai PNS, tentara, polisi dan pegawai BUMN. ${ }^{85}$ Namun demikian, jumlah persebaran ini tidak diketahui secara pasti karena ada perbedaan penggunaan parameter dan definsi antar institusi. ${ }^{86}$

di kerja informal secara umum banyak ditemukan di negara-negara berkembang. Para penyandang disabilitas umumnya memiliki peluang untuk bekerja di sektor informal karena keterbatasan pendidikan, akses informasi atas pasar kerja, keterampilanpraktis dan lingkup sosial yang terbatas akibat proses ekslusi historis dalam masyarakat.

82 Mengenai penelitian ini lihat United Nations, Disability at a Glance 2015 Strengthening Employment Prospects for Persons with Disabilities In Asia and the Pacific (Seoul: Escap Social Development Division, 2015).

83 Lihat grafik dalam United Nations, Disability at a Glance 2015 Strengthening Employment Prospects for Persons with Disabilities In Asia and the Pacific, hlm. 117.

84 Hastuti, dkk., Kendala Mewujudkan Pembangunan Inklusif, hlm. 18.

85 Pusat Data dan Informasi Kementerian Kesehatan RI, Indonesia Inklusi dan Ramah Disabilitas, 2018 (Jakarta: Kementerian Kesehatan, 2018), hlm. 6.

86 Data Kementerian Tenaga Kerja pada 2010 menunjukkan 23,6 persen penyandang disabilitas di seluruh Indonesia yang bekerja dan 1,3 persen di 
Sebab utama rendahnya penyerapan tenaga kerja disabilitas di sektor formal adalah tingkat pendidikan yang rendah dan keterbatasan pilihan lapangan kerja yang tersedia. Pendidikan memiliki pengaruh terhadap tingkat kualitas sumber daya manusia dan pilihan jenis pekerjaan yang bisa dimasuki oleh penyandang disabilitas. Pendidikan tinggi misalnya, berpotensi meningkatkan peluang untuk mendapatkan pekerjaan dan upah yang lebih baik sehingga memberikan jalan keluar dari kemiskinan. ${ }^{87}$ Sebaliknya, pemberi kerja juga memiliki komitmen yang rendah untuk menyerap surplus angkatan kerja dengan disabilitas karena mereka masih memercayai stigma negatif produktivitas dan kualitas kerja yang dihasilkan. Karenanya, kebijakan kuota semestinya diterapkan secara holistik dan tidak hanya dimaksudkan untuk meningkatkan penyerapannya di sektorsektor formal yang sebelumnya memiliki peluang terbatas, tetapi juga mendorong peningkatan kualitas pendidikan dan keahlian praktis yang bermanfaat dalam membantu mereka masuk pada dunia kerja.

Selain itu, pemberi kerja juga harus membuat akomodasi yang wajar (reasonable accomodation) untuk memenuhi kebutuhan karyawan atau calon pelamar dari penyandang disabilitas seperti perubahan pada gedung, penyediaan adaptasi teknologi atau memastikan bahwa kebutuhan-kebutuhan mereka bisa terpenuhi. ${ }^{88}$ Akomodasi yang wajar merupakan bentuk afirmasi melalui modifikasi dan penyesuaian proporsional yang diperlukan untuk memastikan penyandang disabilitas menikmati posisi kesetaraan sebagaimana kebebasan dasar manusia yang fundamental..$^{89}$ Sejak lama, sebagian

antaranya bekerja bekerja sebagai PNS, tentara dan polisi, dan 0,1 persen bekerja di BUMN dan Badan Usaha Milik Daerah (BUMD). Lihat Suhartoyo, "Perlindungan Hukum terhadap Pekerja/Buruh Penyandang Disabilitas di Indonesia”, Masalah-Masalah Hukum, 43, 4 (2014), hlm. 472.

87 Lamichhane, Disability, Education and Employment, hlm. 38.

88 David Goss, Fiona Goss, dan Derek Adam-Smith, "Disability and Employment: a Comparative Critique of UK Legislation”, The International Journal of Human Resource Management, 11, 4 (2000), hlm. 881.

89 United Nations, "Toolkit on Disability for Africa the Right of Persons with Disabilities to Work", https://www.un.org/development/desa/disabilities/news/dspd/toolkit-on-disability-for-africa.html, diakses 12/9/2020. 
pekerjaan di sektor publik dan privat umumnya tidak memiliki sistem kerja khusus yang dirancang agar para penyandang disabilitas dapat beradaptasi dengan lingkungan dan rekan kerja. Dalam konteks ini, pemberi kerja juga harus berkontribusi membentuk budaya anti-diskriminasi di antara sesama rekan kerja sesuai dengan paradigma masyarakat yang inklusif. Bagaimanapun, kewajiban kuota dan bentuk kebijakan penunjang aksesibilitas bagi akomodasi penyandang disabilitas bukan kebijakan sektoral yang berjalan secara terpisah, karena ia adalah bagian dari pemenuhan hak atas penyandang disabilitas yang lebih luas.

Meskipun kuota bersifat wajib bagi pemberi kerja, UU Penyandang Disabilitas tidak mengatur lebih lanjut pemberian sanksi terhadap pemberi kerja yang tidak mematuhi kuota. Laporan ILO menilai sistem kuota yang dianut oleh rezim hukum disabilitas di Indonesia pada dasarnya masih bersifat sukarela sehingga berpotensi menjadi tidak efektif. ${ }^{90}$ Dalam hal ini UU Penyandang Disabilitas hanya memuat sanksi yang diberikan pada pemberi kerja yang tidak menyediakan akomodasi dan aksesibilitas yanglayak bagi penyandang disabilitas. Hal ini pada gilirannya ikut mempengaruhi rendahnya partisipasi para penyandang disabilitas yang ikut didukung pula oleh rendahnya penegakan hukum untuk memastikan kepatuhan pemberi kerja terhadap sistem kuota. Pada kenyataannya, penyerapan tenaga kerja penyandang disabilitas di sektor publik dan privat masih sangat rendah karena penerapannya masih bergantung pada etikat baik (goodwill) dan komitmen politik pemerintah terhadap hak-hak penyandang disabilitas. ${ }^{91}$ Sebagaimana nanti diuraikan dalam bagian berikutnya, meskipun rezim hukum disabilitas di Indonesia secara resmi menganut model disabiltias sosial, ada beberapa peraturan perundang-undangan operasional — terutama yang mengatur masalah kesempatan kerja di sektor publik baru-baru ini-masih menganut paradigma lama yang menempatkan para penyandang disabilitas

90 International Labour Organization, Mewujudkan Peluang Kerja yang Setara bagi Penyandang Disabilitas Melalui Perundang-Undangan Petunjuk Pelaksanaan (Jakarta: International Labour Organization, 2013), hlm. 23.

91 Irwanto, dkk., Analisis Situasi Penyandang Disabilitas, hlm. 17. 
dalam konteks medis, alih-alih masalah struktur sosial. Pendekatan ini pada gilirannya menghambat tercapainya partisipasi penuh para penyandang disabilitas di sektor publik.

\section{Formasi Khusus}

Formasi khusus mulai diperkenalkan pada 2018 dengan tujuan untuk meningkatkan partisipasi penyandang disabilitas pada instansi pemerintahan yang telah ditentukan oleh pemerintah. Sebagaimana dicantumkanpadalampiranPermenPAN-RB2018, instansidiwajibkan mengalokasikan penetapan kebutuhan jabatan, persyaratan, jumlah dan unit penempatan yang dapat dilamar oleh penyandang disabilitas sesuai dengan kebutuhan formasi jabatan paling sedikit dua persen untuk pusat dan satu persen untuk daerah dari total formasi yang disesuaikan dengan kebutuhan masing-masing instansi. Peraturan ini merupakan pedoman utama bagi instansi pemerintah pusat dan pemerintah daerah yang biasanya diperbarui setiap tahunnya dalam proses pengadaaan belanja pegawai. Mempertimbangkan bahwa pada 2018 akan dibuka 238.015 formasi yang terdiri dari 51.271 untuk pusat dan 186.744 untuk daerah, kebijakan sistem kuota membuka peluang kursi sebanyak 1025 formasi untuk pusat dan 1867 untuk daerah yang akan diisi oleh para penyandang disabilitas. Pelamar penyandang disabilitas dipersyaratkan memiliki kualifikasi pendidikan yang sesuai untuk kebutuhan formasi khusus yang telah diagendakan oleh setiap instansi dengan jabatan dan kualifikasi pendidikan yang sama dengan pelamar pada jalur formasi umum. Selain itu, calon pelamar juga wajib melampirkan surat keterangan dokter yang menerangkan ragam/tingkat disabilitasnya dan wajib diverifikasi oleh petugas untuk memastikan kesesuaiannya dengan jenis pekerjaan yang dilamar.

Meskipun dipandang sebagai salah satu solusi yang cepat untuk meningkatkan partisipasi penyandang disabilitas dalam penyelenggaraan negara, kebijakan formasi khusus berpotensi memunculkan diskriminasi baru karena menempatkan penyandang disabilitas pada pilihan bidang kerja yang telah ditentukan sebelum- 
nya oleh pemerintah. Formasi khusus mempersempit peluang yang diperoleh pelamar penyandang disabilitas pada bidang-bidang di luar latar belakang pendidikan yang telah disyaratkan. Seorang pelamar disabilitas yang memiliki latar belakang pendidikan selain pendidikan guru misalnya, tidak dapat melamar pada lowongan yang ditentukan dalam formasi umum. Mereka tidak dapat melamar melalui jalur umum dengan kompetisi secara terbuka bersama individu nondisabilitas lainnya karena persyaratan medis yang dibebankan pada pelamar sejak awal bisa menggugurkan penyandang disabilitas. Mengingat persyaratan yang berbeda antara satu instansi dengan instansi yang lainnya, penyandang disabilitas pada dasarnya memiliki peluang yang lebih kecil untuk lolos jika mereka memaksakan diri mendaftar pada jalur umum. ${ }^{92}$ Dengan kata lain, calon pelamar PNS dengan disabilitas hanya dapat melamar apabila ada formasi khusus yang sesuai dengan latar belakang pendidikan dan persyaratan medis sehat jasmani dan rohani. ${ }^{93}$ Meskipun formasi ini dapat dikatakan sesuai dengan UU Penyandang Disabilitas yang mensyaratkan satu persen kuota untuk pemerintah daerah, jumlah ini, bagaimanapun, tidak sepenuhnya mewakili tingkat keterlibatan penyandang disabilitas yang lebih besar di sektor publik. Jumlah yang akan diterima dari ketersediaan formasi yang ada berpotensi lebih kecil karena

92 Bentuk diskriminasi ini dapat dilihat dalam kasus pembatalan penerimaan PNS Drg. Romi Sofpa Ismael di Kabupaten Solok Selatan pada 2018, seorang dokter gigi di rumah sakit umum yang menggunakan kursi roda. Status kelulusan Drg. Romi dibatalkan karena, pertama, ia mendaftar pada jalur formasi umum, bukan jalur formasi khusus bagi penyandang disabilitas, dan kedua, kondisinya yang duduk di kursi roda dalam memeriksa pasien. Pokok permasalahan dari kasus ini ialah tidak ada formasi khusus yang dibuka sesuai dengan latar belakang dan profesinya sebagai seorang dokter gigi sehingga ia harus mendaftar pada jalur formasi umum yang menyediakan lowongan untuk dokter gigi PNS. Meskipun pada akhirnya dapat diselesaikan dengan dukungan Komnas HAM pada awal tahun 2019, kasus ini menggambarkan bagaimana formasi khusus, alih-alih memberikan kesempatan yang luas bagi penyandang disabiltias untuk mendaftar pada bidang yang sesuai dengan minat dan latar belakang pendidikannya, justru membatasi pilihan penyandang disabilitas.

93 Lihat Slamet Thohari, "Pandangan Disabilitas dan Aksesibilitas Fasilitas publik bagi Penyandang Disabilitas di Kota Malang”, Indonesian Journal of Disability Studies, 1, 1 (2014): 27-37. 
calon pelamar terlebih dahulu melewati tahapan seleksi yang ketat.

Menurut Nursyamsi, formasi khusus penyandang disabilitas pada 2018 secara nasional pada kenyataannya hanya mencakup 0,013 persen dari total penyandang disabilitas yang diperkirakan mencapai 21.843.588 orang. ${ }^{94}$ Kondisi ini diperburuk dengan keterbatasan aturan dalam UU Penyandang Disabilitas sebagai panduan bagi pemerintah daerah melakukan pengadaan terhadap jumlah lowongan yang tepat yang paralel dengan tingkat pengangguran penyandang disabilitas di daerah. ${ }^{95}$ UU Penyandang Disabilitas misalnya tidak memuat penjelasan bagaimana penjabaran yang lebih rinci dari sistem kuota yang diadopsi sehingga implementasi di lapangan mungkin akan sangat bergantung pada persepsi dan pengetahuan pembentuk kebijakan. Singkatnya, ketersediaan jumlah kuota bagi pelamar disabilitas tidak lantas membuat mereka secara pasti diterima sebagai PNS karena sistem kuota hanya menjamin kesempatan yang sama untuk mendaftar pada formasi khusus.

Kebijakan formasi khusus juga bertentangan dengan prinsip pilihan bebas yang diakomodasi oleh CRPD di mana para penyandang disabilitas memiliki otonomi untuk menentukan bidang pekerjaan mana yang sesuai dengan minat dan bakatnya. Dalam perspektif model sosial disabilitas, fokus terhadap penghapusan hambatan semestinya bukan diarahkan pada pembentukan jalur yang 'terpisah' dan telah ditentukan sebelumnya oleh pemerintah sebagai pemberi

94 Lihat Pusat Data dan Informasi Kementerian Kesehatan, Indonesia Inklusi dan Ramah Disabilitas, hlm. 7.

95 Sebagai contoh, Badan Pusat Statistik di level pemerintahan daerah masih menempatkan penyandang disabilitas sebagai bagain dari kelompok penyandang masalah kesejahteraan sosial untuk menghitung jumlah populasi penyandang disabilitas di wilayah yurisdiksi lokal. Statistik terakhir pada 2016 misalnya, mengategorikan 26 jenis penyandang masalah kesejahteraan sosial di antaranya, penderita HIV/AIDS, pemulung, pengemis, anak dengan disabilitas (di bawah 18 tahun), penyandang disabilitas dewasa (di atas 18 tahun), bekas warga binaan, anak jalanan, tuna susila, dan lain sebagainya. Parameter ini mengacu pada Undang-Undang Nomor 11 Tahun 2009 Kesejahteraan Sosial yang dalam perspektif CRPD, masih menggunakan model disabilitas medis. Akibatnya sistem kebijakan kuota minimum satu persen tidak betul-betul menyentuh kondisi rill untuk penyerapan jumlah pengangguran penyandang disabilitas di daerah. 
kerja. Alih-alih mendorong adanya pembangunan lingkungan kerja yang inklusif, formasi khusus dapat menciderai hak atas pekerjaan bagi penyandang disabilitas karena mereka dicirikan oleh hambatan medis yang diidentifikasi dari perbedaan ciri fisik dan mental tertentu. ${ }^{96}$ Karenanya, dalam proses rekrutmen di level lokal (dan nasional) kebijakan formasi khusus ditafsirkan sebagai satu-satunya pintu kesempatan kerja bagi para penyandang disabilitas yang berminat melamar sebagai PNS.

\section{Persyaratan Medis}

Salah satu persyaratan yang dibebankan kepada penyandang disabilitas dalam UU ASN dan termasuk Permen PAN-RB 2018 adalah persyaratan medis yang diberikan oleh dokter untuk menerangkan jenis dan tingkat disabilitas seseorang. Dengan cara ini dokter akan memberikan semacam rekomendasi tertulis kepada panitia seleksi di tingkat lokal yang menilai apakah calon pelamar dengan disabilitas tertentu secara medis sesuai dengan jenis pekerjaan dan beban kerja yang akan diterimanya apabila lolos ujian. Persyaratan ini juga diakomodasi dalam pengertian pelamar penyandang disabilitas yang digunakan di berbagai daerah, di mana penyandang disabilitas dipandang sebagai pelamar berkebutuhan khusus yang telah melakukan pemeriksaan kesehatan dan dinyatakan dapat melaksanakan tugas kedinasan apabila diterima sebagai calon PNS.

Bagaimanapun, pengertian ini tidak sejalan dengan UU Penyandang Disabilitas yang semestinya didefinisikan sebagai "orang yang memiliki keterbatasan fisik, mental, intelektual dan/ atau sensorik dalam jangka waktu lama yang dalam berinteraksi dengan lingkungan dapat mengalami hambatan dan kesulitan untuk berpartisipasi secara penuh dan efektif dengan warga negara lainnya

96 Kebijakan inklusif tidak hanya mencakup kebijakan kuota yang mewajibkan pemberi kerja (baik pengusaha swasta maupun pemerintah) saja, melainkan juga penguatan kapasitas imaterial seperti peningkatan sumber daya melalui pelatihan, penyediaan fasilitas penterjemahan aksara latin ke aksara braile bagi tunanetra, pengitegrasian teknologi baru yang dapat meringankan kerja penyandang disabilitas, kampanye anti-diskriminasi bagi sesama rekan kerja non-disabilitas di kantor dan sebagainya. 
berdasarkan kesamaan hak." Persyaratan medis menempatkan penyandang disabilitas sebagai entitas dengan ciri fisik tertentu dan dengan demikian hanya mampu melamar pada instansi-instansi yang dipandang cocok dengan bentuk pekerjaan yang dapat dikerjakan oleh keterbatasan fisik tertentu. Dalam konteks penerimaan PNS guru di tingkat daerah misalnya, persyaratan medis sehat jasmani dan rohani tidak sesuai dengan ketentuan Undang-Undang Nomor 14 Tahun 2005 tentang Guru dan Dosen di mana persyaratan sehat jasmani dan rohani tidak ditujukan kepada penyandang 'cacat' (Penjelasan Pasal 8 dan Pasal 45). Padahal kondisi fisik yang terbatas belum tentu menjadi hambatan bagi orang-orang dengan disabilitas yang memilikinya sehingga persyaratan semacam ini tampak menjadi lebih absurd dalam penerapannya. ${ }^{97}$ Di samping itu, persyaratan usia juga menjadi sasaran kritik bagi gerakan masyarakat sipil karena pada umumnya para penyandang disabilitas, terutama disabilitas intelektual, baru siap secara mental untuk bekerja pada usia 28 tahun. ${ }^{98}$ Alih-alih mendorong tindakan diskriminasi positif, generalisasi batas usia untuk pelamar penyandang disabilitas justru berpotensi menghasilkan diskriminasi negatif tanpa melihat dahulu ragam atau jenis disabilitas yang dihadapi.

Penggunaan definisi operasional dalam PermenPAN-RB 2018 mengindikasikan bahwa panitia seleksi akan menerima calon pelamar penyandang disabilitas hanya jika kondisi disabilitas pada fisik, intelektual, mental atau sensoriknya dapat direhabilitasi menurut pandangan medis dengan tujuan meringankan hambatan fisik yang dihadapi ketika bekerja. Dalam model disabilitas medis, 'kondisi kecacatan dapat menyebabkan seseorang tidak dapat memenuhi kewajibannya sebagai seorang pekerja' dan karena itulah persyaratan medis diperlukan oleh lembaga pemberi kerja untuk memastikan tingkat disabilitas para pelamar berada pada status yang

97 Nursyamsi, dkk., Kerangka Hukum Disabilitas di Indonesia, hlm. 48.

98 IDN Times, "Penyandang Disabilitas Soroti Syarat Sehat Jasmani dan Rohani CPNS", https://www.idntimes.com/news/indonesia/aldzahfatimah-aditya/penyandang-disabilit -as-soroti-syarat-sehat-jasmani-danrohani-cpns / full, diakses 12/9/2020. 
'wajar' tanpa menghambat pekerja dalam beraktivitas. ${ }^{99}$ Padahal di lapangan, pemberi kerja secara umum masih lebih memilih mempekerjakan pekerja non-disabilitas yang dipercaya memiliki produktivitas dan mobilitas yang lebih prima dalam menjalankan pekerjaan. 'Permasalahan yang sering dihadapi organisasi adalah cara pandang yang masih bias ketika proses seleksi tes dilaksanakan', ketidakpahaman pemberi kerja dalam berkomunikasi dengan cara yang 'berbeda' dengan para pelamar penyandang disabilitas dan kekhawatiran tentang penambahan beban biaya yang mungkin ditimbulkan untuk menyesuaikan kondisi tempat kerja untuk penyandang disabilitas. ${ }^{100}$ Di samping itu, berdasarkan studi Thohari, banyak bangunan gedung pemerintahan daerah juga tidak aksesibel bagi penyandang disabilitas yang menghambat pekerja atau masyarakat dengan disabilitas melakukan aktivitas di gedung pemerintahan. ${ }^{101}$ Kondisi ini menggambarkan tidak adanya akomodasi yang wajar bagi penyandang disabilitas yang seharusnya menjadi salah satu prioritas utama untuk membentuk diversitas lingkungan kerja.

Pada kenyataannya, persyaratan medis kerap menghambat pencari kerja dengan ragam disabilitas tertentu yang banyak terjadi di berbagai bidang pekerjaan. Stigma terhadap keterbatasan fisik di kalangan pemberi kerja dipercaya akan menghambat mobilitas penyandang disabilitas untuk bekerja yang pada gilirannya akan mempengaruhi kinerja suatu organisasi. ${ }^{102}$ Jazim Hamidi mengkritik persyaratan-persyaratan semacam ini yang membuat aturan-aturan hukum menjadi tidak relevan, bertentangan dengan keadilan dan menggelikan. ${ }^{103}$ Konsep kesehatan jasmani dan rohani semestinya harus dimaknai secara komprehensif, yaitu kesehatan

99 Theresia Degener, "Disability in a Human Rights Context", Laws, 35, 3 (2016), hlm. 3.

100 Abdul Latif Danu Aji dan Tiyas Nur Haryani, "Diversitas dalam Dunia Kerja: Peluang dan Tantangan bagi Penyandang Disabilitas", Jurnal Spirit Publik, 12, 2 (2017), hlm. 90.

101 Thohari, "Pandangan Disabilitas dan Aksesibilitas", hlm. 32.

102 Nada Sakinah, "Implementation of Public Servant Recruitment Toward Disabilities in Jakarta and East Java”, Journal of Administrative Science and Organization, 19, 1 (2012), hlm. 34.

103 Hamidi, "Perlindungan Hukum terhadap Disabilitas", hlm. 665. 
yang memungkinkan seseorang menjadi produktif dalam konteks kehidupan sosial dan ekonomi. ${ }^{104}$ Fokus terhadap penghapusan hambatan semestinya tidak dilakukan dengan membatasi penyandang disabilitas pada instansi-instansi yang telah disiapkan sedemikian rupa melalui formasi khusus, melainkan mempersiapkan seluruh instansi untuk menyiapkan akses yang layak bagi penyandang disabilitas selama bertugas. Persyaratan sehat jasmani dan rohani tidak dapat menjadi syarat yang menentukan terpilih atau tidaknya seseorang karena hal ini belum tentu memengaruhi yang bersangkutan dalam menjalankan tugasnya. ${ }^{105}$ Persyaratan medis tidak menciptakan implementasi hak atas pekerjaan bagi penyandang disabilitas di sektor publik karena menghambat terciptanya inklusi lingkungan kerja yang dimulai dari hulu dalam proses mekanisme rekrutmen.

\section{F. Kesimpulan}

UU Penyandang Disabilitas dan CRPD merupakan kerangka hukum yang bertujuan untuk menghormati, memajukan dan melindungi martabat dan hak-hak penyandang disabilitas, termasuk hak atas pekerjaan di sektor publik. UU ini memandang disabilitas sebagai masalah hambatan struktural dan lingkungan sosial, ekonomi, politik dan kebudayaan yang menjadikan para penyandang disabilitas tidak dapat menikmati hak yang sama sebagai warga negara. Pemenuhan hak atas pekerjaan bagi penyandang disabilitas dilakukan melalui intervensi aktif negara dalam pasar tenaga kerja guna meningkatkan taraf kesejahteraannya. Namun, meskipun rezim hukum disabilitas yang ada mengadopsi model disabilitas sosial sebagai pedoman pembentukan kebijakan yang terkait dengan pemenuhan hak penyandang disabilitas, implementasinya dalam bidang ketenagakerjaan di sektor publik masih didasarkan pada model disabilitas medis di mana para penyandang disabilitas diidentifikasi berdasarkan kondisi fisik dan dengan demikian diasumsikan hanya mampu masuk pada bidang-bidang pekerjaan di sektor publik yang

104 Sakinah, "Implementation of Public Servant Recruitment”, hlm. 42. 105 Nursyamsi, dkk., Kerangka Hukum Disabilitas di Indonesia, hlm. 48. 
telah ditentukan oleh negara. Terlepas dari komitmen normatifnya, kerangka hukum dan kebijakan yang tersedia tidak dirancang untuk memfasilitasi jenis dan kondisi pendukung yang merupakan prasyarat bagi realisasi hak-hak penyandang disabilitas.

Hambatan inklusi ketenagakerjaan di sektor publik juga didukung oleh UU ASN yang secara eksplisit menganut persyaratan medis yang disesuaikan dengan kebutuhan pekerjaan tanpa penjelasan lebih rinci mengenai kriteria medis yang dimaksud. Formasi khusus dan persyaratan medis pada gilirannya merupakan bentuk diskriminasi terhadap penyandang disabilitas yang dilembagakan yang tidak memberikan peluang setara karena keterbatasan fisik untuk melamar pada bidang pekerjaan ASN sesuai dengan minat dan latar belakang pendidikannya. Dalam praktiknya, keterbatasan ini juga dipengaruhi oleh faktor eksternal seperti tidak adanya data tentang angkatan kerja dengan ragam disabilitas, aksesibilitas yang buruk dan tidak inklusif, serta stigma negatif dalam lingkungan kerja terhadap penyandang disabilitas.

Artikel ini menunjukkan, fokus pemenuhan hak atas pekerjaan bagi penyandang disabilitas semestinya juga didukung oleh reformasi ketenagakerjaan di sektor publik yang terbuka, inklusif dan aksesibel yang diarahkan untuk menghapus hambatan dan diskriminasi di lingkungan kerja. Artikel ini merekomendasikan untuk menghapus kebijakan formasi khusus dan sistem kuota dan memperluas kesempatan penyandang disabilitas dalam proses rekrutmen ASN guna mengatasi masalah diskriminasi yang dihadapi penyandang disabilitas berdasarkan kondisi fisiknya. Riset lebih lanjut mengenai kebijakan rekrutmen yang berorientasi pada semangat anti-diskriminasi dan kesempatan yang sama bagi penyandang disabilitas tentu saja sangat diperlukan untuk pengembangan sistem alternatif dalam pembuktian kompetensi yang mempertemukan profesionalitas dan inklusivitas sosial. Pemberian kesempatan yang sama juga harus diiringi dengan pemenuhan aksesibilitas dan sarana akomodasi yang dapat mendukung tugas dan kewajiban penyandang disabilitas selama bekerja. Dalam konteks yang lebih luas, artikel ini juga mendorong penelitian hukum HAM yang mengambil sudut 
pandang lebih radikal dalam membongkar persoalan marjinalisasi hak-hak penyandang disabilitas dalam berbagai aspek sosial, ekonomi, politik dan kebudayaan.

\section{Daftar Pustaka}

Adioetomo, Sri Moertiningsih, dkk. Person with Disabilities in Indonesia Empirical Facts and Implications for Social Protection Policies. Jakarta Pusat: TNP2K, 2014.

Agustian, Hendra Y. "Redefining Disability in the Context of Masyarakat Madani an Indonesian Model of Inclusive Society". British Journal of Special Education, 43, 4 (2016): 358-72. DOI: 10.1111/1467-8578.12152.

Aji, Abdul Latif Danu dan Tiyas Nur Haryani. "Diversitas dalam Dunia Kerja: Peluang dan Tantangan bagi Penyandang Disabilitas”. Jurnal Spirit Publik, 12, 2 (2017): 83-93. DOI: 10.2096/ sp.v12i2.16246.

Albin, Einat. "Universalizing the Right to Work of Persons with Disabilities: An Equality and Dignity Based Approach". Hebrew University of Jerusalem Legal Studies Research Paper Series, 15, 9 (2015): 1-22.

Ali, Syarif . "Indonesian Civil Service Management and Corruption". Asia Pacific Fraud Journal 4, 1 (2019): 16-26. DOI: 10.21532/ apfj.001.19.04.01.02.

Blomkamp, Emma, dkk. Understanding Policymaking in Indonesia: In Search of a Policy Cycle. Jakarta: PSHK \& University of Melbourne, 2017.

Broderick, Andrea. "Harmonisation and Cross-Fertilisation of SocioEconomic Rights in the Human Rights Treaty Bodies: Disability and the Reasonableness Review Case Study". Laws, 38, 5 (2016): 1-18. DOI: 10.3390/laws5040038.

Butt, Simon dan Tim Lindsey. Indonesian Law. Oxford: Oxford University Press, 2018.

Colbran, Nicola. "Access to Justice Persons with Disabilites in Indonesia”. Background Assessment Report, AusAID, 2010. 
Degener, Theresia. "Disability in a Human Rights Context". Laws, 35, 3 (2016): 1-24. DOI: 10.3390/laws5030035.

Edwards, Nicola. "Disability Rights in Indonesia? Problems with Ratification of the United Nations Convention on the Rights of Persons with Disabilites". Australian Journal of Asian Law, 15, 1 (2014): 1-15.

Fakih, Mansour. "The Role of Non-Governmental Organization in Social Transformation: a Participatory Inquiry in Indonesia”. Disertasi, University of Massachusetts, Boston, 1996.

Fasciglione, Marco. "Article 27 of the CRPD and the Right of Inclusive Employment of People with Autism". Dalam Protecting the Rights of People with Autism in the Fields of Education and Employment, diedit oleh Valentina Della Fina dan Rachele Cera,1-32. London: Springer, 2015.

Goodale, Mark. "The Globalization of Sympathetic Law and Its Consequences”. Law \& Social Inquiry, 27, 3 (2002): 595-608. DOI: 10.1111/j.1747-4469.2002.tb00817.x.

Goss, David, Fiona Goss, dan Derek Adam-Smith. "Disability and Employment: a Comparative Critique of UK Legislation". The International Journal of Human Resource Management 11, 4 (2000): 807-21. DOI:10.1080/09585190050075132.

Grischow, Jeff D. "I Nearly Lost my Work: Chance Encounters, Legal Empowerment and the Struggle for Disability Rights in Ghana”. Disability and Society, 30, 1 (2015): 101-13. DOI: $10.1080 / 09687599.2014 .982786$.

Hamidi, Jazim. "Perlindungan Hukum terhadap Disabilitas dalam Memenuhi Hak Mendapatkan Pendidikan dan Pekerjaan”. Jurnal Hukum Ius Quia Iustum, 32, 4 (2016): 652-71. DOI: 10.20885/ iustum.vol23.iss4.art7.

Hastuti, Rika Kumala Dewi, Rezanti Putri Pramana, dan Hariyanti Sadaly. Kendala Mewujudkan Pembangunan Inklusif terhadap Penyandang Disabilitas, diedit oleh Dhania Putri Sarahtika dan Liza Hadiz. Jakarta: SMERU Research Institute, 2019.

IDN Times. "Penyandang Disabilitas Soroti Syarat Sehat Jasmani dan Rohani CPNS”. https://www.idntimes.com/news/indonesia/ 
aldzah-fatimah-aditya / penyandang-disabilitas-soroti-syaratsehat-jasmani-dan-rohani-cpns/full, 5/9/2019. Diakses $12 / 9 / 2020$.

International Labour Organization. Mewujudkan Peluang Kerja yang Setara bagi Penyandang Disabilitas Melalui Perundang-Undangan PetunjukPelaksanaan.Jakarta:International Labour Organization, 2013.

Irwanto dan Slamet Thohari. "Understanding CRPD Implementation in Indonesia”. Dalam Making Disability Rights Real in Southeast Asia Impelementing the UN Convention on the Rights of Persons with Disabilities in ASEAN, diedit oleh Derrick L. Cogburn danTina Kempin Reuter, 91-118. London: Lexington Books, 2017.

Irwanto, dkk. Analisis Situasi Penyandang Disabilitas di Indonesia: sebuah Desk Review. Jakarta: Pusat Kajian Disabilitas Fisip UI dan AusAID, 2010.

Kanter, ArleneS. The Development of DisabilityRights UnderInternational Law from Charity to Human Rights. Oxon: Routledge, 2017.

Kayess, Rosemary dan Phillip French. "Out of Darkness into Light? Introducing the Convention on the Rights of Persons with Disabilites”. Human Rights Law Review, 8, 1 (2008): 1-34. DOI: $10.1093 / \mathrm{hrlr} / \mathrm{ngm} 044$.

Kristianten, Stein dan Muhid Ramli. "Buying an Income: the Market for Civil Service Positions in Indonesia". Contemporary Southeast Asia, 28, 2 (2006): 207-33. DOI: 10.1353/ csa.2006.0020.

Lamichhane, Kamal. Disability, Education and Employment in Developing Countries From Charity to Investment. New Delhi: Cambridge University Press, 2015.

Lawson, Anna dan Mark Priestley. "The Social Model of Disability Questions for Law and Legal Scholarship?”. Dalam Routledge Handbook of Disablity Law and Human Rights, diedit oleh Peter Blanck dan Eilionoir Flynn, 1-13. Oxon: Routledge, 2017.

Lindsey, Tim. "Indonesia Devaluing Asian Values, Rewriting rule of Law". Dalam Asian Discourses of Rule of Law Theories and Implementation of Rule of Law in Twelve Asian Countries, France and the US, diedit oleh Randall Pereenboom, 286-323. New York: 
Routledge, 2004.

Maharromova, Elza. "Disability Employment Policies within the Civil

Service, Managing Diversity in the Civil Service". UNDESA-

IIAS, Managing Diversity in the Civil Service. Amsterdam: IOS Press, 2002.

McCallum, Ron. "The United Nations Convention on the Rights of

Persons with Disabilities: Some Reflection”. Sydney Law School Legal Studies Research Paper, 10, 30 (2010): 1-16.

Meekosha, Helen dan Karen Soldatic. "Human Rights and the Global

South: the Case of Disability”. Third World Quarterly, 38, 8(2011):

1383-97. DOI: 10.1080/01436597.2011.614800.

Meyers, Stephen, Valerie Karr, dan Victor Pineda. "Youth with Disabilities in Law and Civil Society: Exclusion and Inclusion in Public Policy and NGO Networks in Cambodia and Indonesia”. Disability and the Global South, 1, 1 (2014): 5-28.

Miles, M. "Disability on a Different Model: Glimpses of an Asian Heritage”. Disability and Society, 15, 4 (2000): 603-18. DOI: 10.1080/09687590050058206.

Mubin, Fauzul dan Ali Roziqin. "Meritocracy of Bureaucracy in Indonesia". International Journal of Social Science and Humanity, 8, 8 (2018): 241-46. DOI: 10.18178/ijssh.2018.V8.968.

Nursyamsi, Fajri. "Formasi Khusus Disabilitas CPNS 2018: Pisau Bermata Dua”. https: / pshk.or.id/blog-id/ formasi-khusus-disabilitas-cpns-2018-pisau-bermata-dua/. Diakses 22/8/2020.

Nursyamsi, Fajri, dkk. Kerangka Hukum Disabilitas di Indonesia Menuju Indonesia Ramah Disabilitas. Jakarta: Pusat Studi Hukum dan Kebijakan Indonesia, 2015.

Purwanto, Erwan Agus, Agus Pramusinto, dan Dwiyanto Indiahono. "Politics-Administration on the Dynamic Relations of Elected Officials and Bureaucracy in the Recruitment of Local Career Officials". Advances in Social Science, Education and Humanities Research, 191 (2018): 437-51. DOI: 10.2991/aapa-18.2018.41.

Pusat Studi Hukum \& Kebijakan Indonesia. "Siaran Pers Koalisi Masyarakat Penyandang Disabilitas”. https:/ / pshk.or.id / publikasi / siaran-pers / siaran-pers-koalisi-masyarakat-penyandang- 
disabilitas/, 29/5/2020. Diakses 7/9/2020.

Republik Indonesia, Dewan Perwakilan Rakyat. Naskah Akademik Rancangan Undang-Undang tentang Penyandang Disabilitas. Jakarta: DPR RI, tanpa tahun.

Republik Indonesia, Dewan Perwakilan Rakyat. Risalah Rapat Kerja Komisi VIII DPR RI dengan Menteri Sosial dan Kementerian Lainnya terkait RUU Penyandang Disabilitas, Masa Sidang III 2015-2016, Ruang Rapat Komisi VIII DPR RI, 20/1/2016.

Republik Indonesia, Komnas HAM. Komentar Umum Kovenan

Internasional Hak Sipil dan Politik dan Kovenan Internasional Hak

Ekonomi Sosial dan Budaya. Jakarta: Komnas HAM, 2009.

Republik Indonesia, Komnas HAM. Marjinalisasi Hak Politik

Penyandang Disabilitas. Jakarta Barat: Komnas HAM, 2011.

Republik Indonesia, Komnas HAM. Mendorong Pengesahan "Optional

Protocol to the Convention on the Rights of Persons with Disabilities"

(OP CRPD) dalam Rangka Pemenuhan Hak Asasi Manusia

Penyandang Disabilitas. Jakarta Barat: Komnas HAM, 2016.

Republik Indonesia, Pusat Data dan Informasi Kementerian

Kesehatan. Indonesia Inklusi dan Ramah Disabilitas, 2018. Jakarta:

Kementerian Kesehatan, 2018.

Rimmerman, Arie. Social Inclusion of People with Disabilities National and International Perspectives. New York: Cambridge University Press, 2013.

Sakinah, Nada. "Implementation of Public Servant Recruitment Toward Disabilities in Jakarta and East Java". Journal of Administrative Science and Organization, 19, 1 (2012): 34-44.

Sargeant, Malcolm, Elena Radevish-Katsaroumpa, dan Alessandra Innesti. "Disability Quotas: Past or Future Policy?". Economic and Industrial Democracy 39, 3 (2018): 404-21. DOI: 10.1177/0143831X16639655.

Simandjuntak, Marsilam. Pandangan Negara Integralistik. Jakarta: Penerbit Grafitti, 1994.

Suharto, Suharto, Pim Kuipers, dan Pat Dorsett. "Disability Terminology and the Emergence of Diffability in Indonesia”. Disability and Society, 31, 5 (2016): 693-712. DOI: 
10.1080/09687599.2016.1200014.

Suhartoyo. "Perlindungan Hukum terhadap Pekerja/Buruh Penyandang Disabilitas di Indonesia”. Masalah-Masalah Hukum, 43, 4 (2014): 468-78. DOI: 10.14710/mmh.43.4.2014.468-477.

Thohari, Slamet. "Contesting Conceptions of Disability in Javanese Society After the Soeharto Regime: the Case of Yogyakarta Indonesia”. Thesis, University of Hawaii, Hawaii, 2011.

Thohari, Slamet. "Pandangan Disabilitas dan Aksesibilitas Fasilitas publik bagi Penyandang Disabilitas di Kota Malang”. Indonesian Journal of Disability Studies, 1, 1 (2014): 27-37. DOI: 10.21776/ ub.IJDS.2017.004.01.8.

Thornton, Patricia dan Neil Lunt. Employment for Disabled People Social Obligation or Individual Responsibility? New York: Social Policy Research of University of York, 1995.

Thornton, Patricia. "Employment Quotas, Levies and National Rehabilitation Funds for Persons with Disabilities: Pointers for Policy and Practice”. Gladnet Collection Cornell University, 84 (1998): 1-89.

Tjiptoherijanto, Projo. "Civil Service Reform in Indonesia: Culture and Institution Issues". Working Paper in Economics and Business, 2, 7 (2012): 2-10. DOI: 10.47291/ efi.v66i2.703.

United Nations. Disability at a Glance 2015 Strengthening Employment Prospects for Persons with Disabilities In Asia and the Pacific. Seoul: Escap Social Development Division, 2015.

United Nations. "Toolkit on Disability for Africa the Right of Persons with Disabilities to Work". https: / / www.un.org/development/ desa / disabilities / news / dspd/ toolkit-on-disability-for-africa. html. Diakses 12/9/2020.

Universitas Indonesia, Lembaga Penyelidikan Ekonomi dan Masyarakat FE. Laporan Akhir Memetakan Penyandang Disabilitas di Pasar Tenaga Kerja Indonesia. Jakarta: ILO, 2017.

Vornholt, Katharina, dkk. "Disability and Employment-Overview and Highlights". European Journal of Work and Organizational Psychology, 27, 1 (2018): 40-55. DOI: 10.1080/1359432X.2017.1387536.

Waddington, Lisa, Mark Priestley, dan Betul Yalcin. “Equality of 
Opportunity in Employment? Disability Rights and Active Labour Market Policies". Dalam Routledge Handbook of Disability Law and Human Rights, diedit oleh Peter Blanck dan Eilinoir Flynn, 78-87. New York: Routledge, 2017.

Wardana, Agung dan Ni Putu Yogi Paramitha Dewi. "Moving Away from Paternalism: the New Law on Disability in Indonesia". Asia-Pacific Journal on Human Rights and the Law, 18, 1 (2017): 17295. DOI: $10.1163 / 15718158-01802003$.

World Health Organization. World Disability Report. Genewa: WHO \& World Bank, 2011. 